\title{
SECUNDAIRY DATA-ANALYSIS MAPANE-PLOTS 1981-1997
}

\author{
J.J. Jansen ${ }^{1}$, F. Bongers ${ }^{1}$, N.R. de Graaf ${ }^{1}$, W.B.J. Jonkers ${ }^{1}$, F.J. Sterck ${ }^{1}$, B.M. Stuiver ${ }^{1}$ and \\ J. Wirjosentono ${ }^{2}$
}

Wageningen, 2005

1) Forest Ecology and Forest Management Group, Centre for Ecosystem Studies, Wageningen University

2) CELOS - Centre of Agricultural Research in Surinam

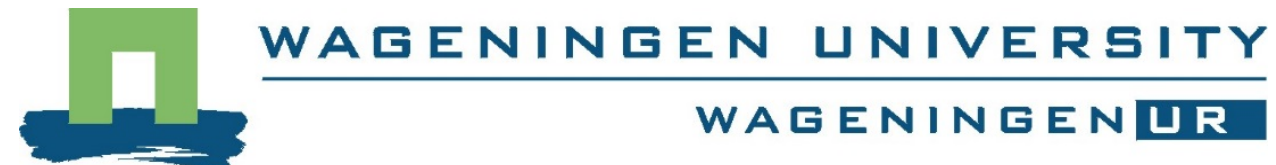


J.J. Jansen, F. Bongers, N.R. de Graaf, W.B.J. Jonkers, F.J. Sterck, B.M. Stuiver and J. Wirjosentono, 2004. Secundairy data-analysis Mapane-plots 1981-1997. WUR Wageningen.

Hence! This page is added in 2018 for the internet version.

Research with the focus on sustainable forest management using natural regeneration has been done in Surinam through a cooperative relation between the Centre of Agricul-tural Rsearch in Surinam (CELOS) and the department of Forest Ecology and Forest Management of the Wageningen University since 1965. This eventually led to the development of the Celos Management System (CMS), which can be split into the Celos Harvesting System (CHS) and the Celos Silvicultural System (CSS). This research has been adjourned in the early eighties.

The Celos Management System is a polycyclic forest management system. Every 20 to 25 years approximately $20 \mathrm{~m} 3 /$ ha of commercial timber species is harvested. The harvest results in a temporary increase in light and growth; also for the commercial species. The annual growth of the commercial species however is not enough to make a new harvest possible. To guarantee a sufficient annual increment $(1 \mathrm{~m} 3 / \mathrm{ha} / \mathrm{yr})$ of the commercial tim-ber species De Graaf proposes to perform a cleaning right after the harvest and after 8 and 16 years a liberation-treatment. In Mapane CSS was tested, and field data were recorded in 1981 and 1997.

In this study the recordings were analyzed and positive results were found within CHS for Hendrisons' controlled logging sytem and within CSS for De Graaf's cleaning with D-rate and up.

The report is open access and downloadable at https://doi.org/10.18174/448970

The study is based on the database FEM Growth and Yield Data - Tropical Lowland Rainforest - Suriname Mapane. 2018 DANS. https://doi.org/10.17026/dans-228-yw96 


\section{Contents}

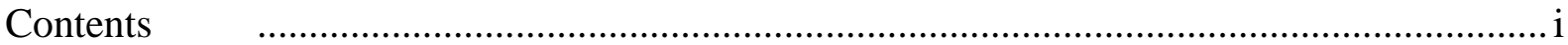

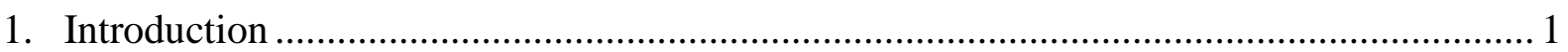

2. Material: Experimental plots and tree data ......................................................... 2

3. Problem definition and research questions.........................................................6 6

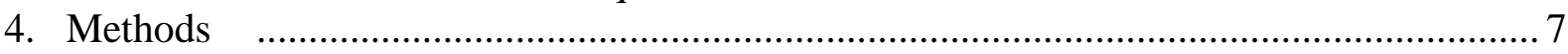

5. Results

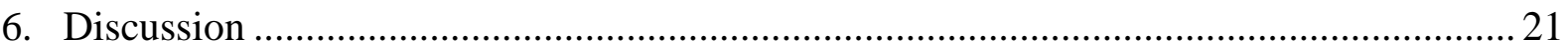

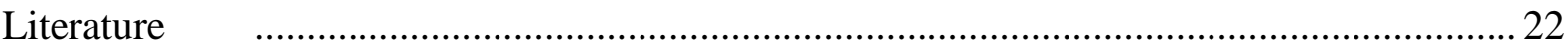

Appendix I. Frequency division timber species and diameter increment (PCQ + PSP) ...... 23

Appendix II. Stem number mutations per tree species and treatment in number per ha

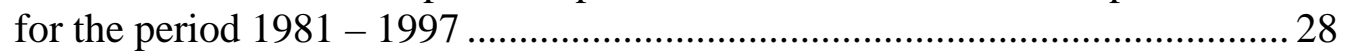

Appendix III. Species list with vernacular name and scientific name................................36

Appendix IV. Terms of Reference: Statistical Analysis of Forest Research Data

(Mapane-Experiment) 


\section{Introduction}

The following report concerns research on a contract basis performed by the Forest Ecology and Forest Management department requested by CELOS. Bus and Laumans conducted a research in the Mapane-area for this department in 1997. The following subscription is pretty much literally cited out of their report (Bus and Laumans, 1997b), although it has been translated.

Research with the focus on sustainable forest management using natural regeneration has been done in Surinam through a cooperative relation between the Centre of Agricultural Research in Surinam (CELOS) and the department of Forest Ecology and Forest Management of the Wageningen University since 1965. This eventually led to the development of the Celos Management System (CMS), which can be split into the Celos Harvesting System (CHS) and the Celos Silvicultural System (CSS). This research has been adjourned in the early eighties.

The Celos Management System is a polycyclic forest management system. Every 20 to 25 years approximately $20 \mathrm{~m}^{3} /$ ha of commercial timber species is harvested. The harvest results in a temporary increase in light and growth; also for the commercial species. The annual growth of the commercial species however is not enough to make a new harvest possible. To guarantee a sufficient annual increment $\left(1 \mathrm{~m}^{3} / \mathrm{ha} / \mathrm{yr}\right)$ of the commercial timber species De Graaf (1986) proposes to perform a cleaning right after the harvest and after 8 and 16 years a liberation-treatment. In experiment 67/9 B (Akintasoela) De Graaf performed the most promising cleaning methods as suggested in previous studies on 25 ha. Taking into consideration the economical and ecological preconditions, this could be promising in the meaning of sufficient annual increment of commercial timber species. The same method has been the base for a practical experiment in natural forest regeneration for the Suriname Forest Service (Dienst Lands Bosbeheer) (De Vletter, 1980). For this matter, a representative area of Mapane-area has been split up in patches of 10 hectares. The intention was to monitor the consequences of cleaning at 23 Permanent Sample Plots of 1 ha each. Deliberately a distinction has been made between a relatively rich and a relatively poor soil, in the Tibiti district in the southern region and the Rama district in the northern region respectively. Hendrison conducted his research on the differences between traditional harvesting methods and controlled harvesting (CHS) within this sample area. After the harvest of 1981 (aim: $15 \mathrm{~m}^{3} /$ ha, effectively 5-6 trees/ha) it was the intention to clean the area according to the method of De Graaf (return the basal area to 12.5 $\left.m^{3} / h a\right)$.

All 23 experimental plots were recorded in 1981/82; a cleaning treatment has been done on part of the experimental plots in 1984. In cooperation with Bus and Laumans, CELOS has recorded all experimental plots again in 1997/98. In 2002, CELOS' department of Forestry placed an Excel-file with the data of both recordings to the disposal of the Department Forest Ecology and Forest Management of the WUR with the request to investigate what conclusions could be drawn out of the data (see appendix IV for the assignment).

First a description and analyses of the available material is given, followed by the problem definition and the formulation of the research questions. These are based on the proposed research question and the possibilities the material offers. The report will follow the usual steps "methods", "results”, and “discussion”. 


\section{Material: Experimental plots and tree data}

In the Mapane district, 23 experimental plots are located that were recorded by Celos in 1981 or 1982 and once again in 1997 and 1998 by Celos in cooperation with Bus and Laumans. The timeframe between the two recordings is approximately 16 years. Certain treatments were carried out in part of the experimental plots in 1984.

\section{Experimental plot data}

The experimental plots were originally planned for monitoring as part of an extensive practical experiment. The map (Figure 1) of treatments suggests a well-constructed experiment in which two variations of the Celos Silvicultural System (CSS) would be tested. Locations were pointed out with a similar starting situation in which untreated (0), S-treatment and D-treatment experimental plots were present. Next to that, there were locations with only two of the three treatments and solitary experimental plots with one of the three treatments, see Figure 1 for the location, code and treatment. However, only the experimental plots with the 0 - and Dtreatment were recorded again. In cases that a cluster consisted of two or three treatments, only one was chosen. Nothing can be recovered from the original location-effect, and thus you can hardly speak of any sort of random sampling outline. It can thus be considered as an imperfect experimental field outline with some effects that could influence growth. For an extensive description of the experiment and analyses of the tree species composition, see Ter Steege et al (2003).

The recordings of 1981/82 (right after the exploitation harvesting) served on one hand to describe the starting situation and on the other hand to quantify the cleaning measurement of 1984. The cleanings should have been a bit earlier in the CSS. Subsequently a liberation treatment should have been done after 8 and 16 years, these were not performed.

Bus and Laumans initially already announced a difference between the North and the South. There is a growth difference between the North and South of Mapane according to Wyb Jonkers (personal announcement). The area northeast of the road (see Figure 1) therefore is indicated as North and the remains as South. There possibly also is a difference in the species distribution between North and south, according to Reitze de Graaf (personal announcement) Brownheart (Vouacapoua americana) occurs in the North while this is hardly the case in the South. Afterwards, this appeared to be the case, but no attention has been paid to it in this research. According to the map several experimental plots are also located in the exploitation patches of Hendrisons' research. Hendrison (1990) makes a distinction between the traditional harvest ( $\mathrm{T}$ ) and the controlled harvesting (C). In the case of controlled harvesting, he has some variations, of which only "winches" appears here, this is not important in this study. Next to this, there is the 0-treatment (not in Hendrison-research).

The treatment of 1984 comes down to the cleaning of all Non Commercial Timber Species (NCTS) above a certain diameter (in such a way that the trees are girdled with the consequence that the tree dies after some time). The diameter is chosen in such a way that afterwards a basal area (including all species) of 12.5-15.0 $\mathrm{m}^{2} /$ ha with a minimal diameter of $25 \mathrm{~cm}$ remains. The data of the experimental plots are listed in Table 1. A lower value in diameter proportionally meant a heavier cleaning. It is a systematical cleaning, with the single criterion of diameter. The individual tree treatments and the distribution over the area are not taking into account. 


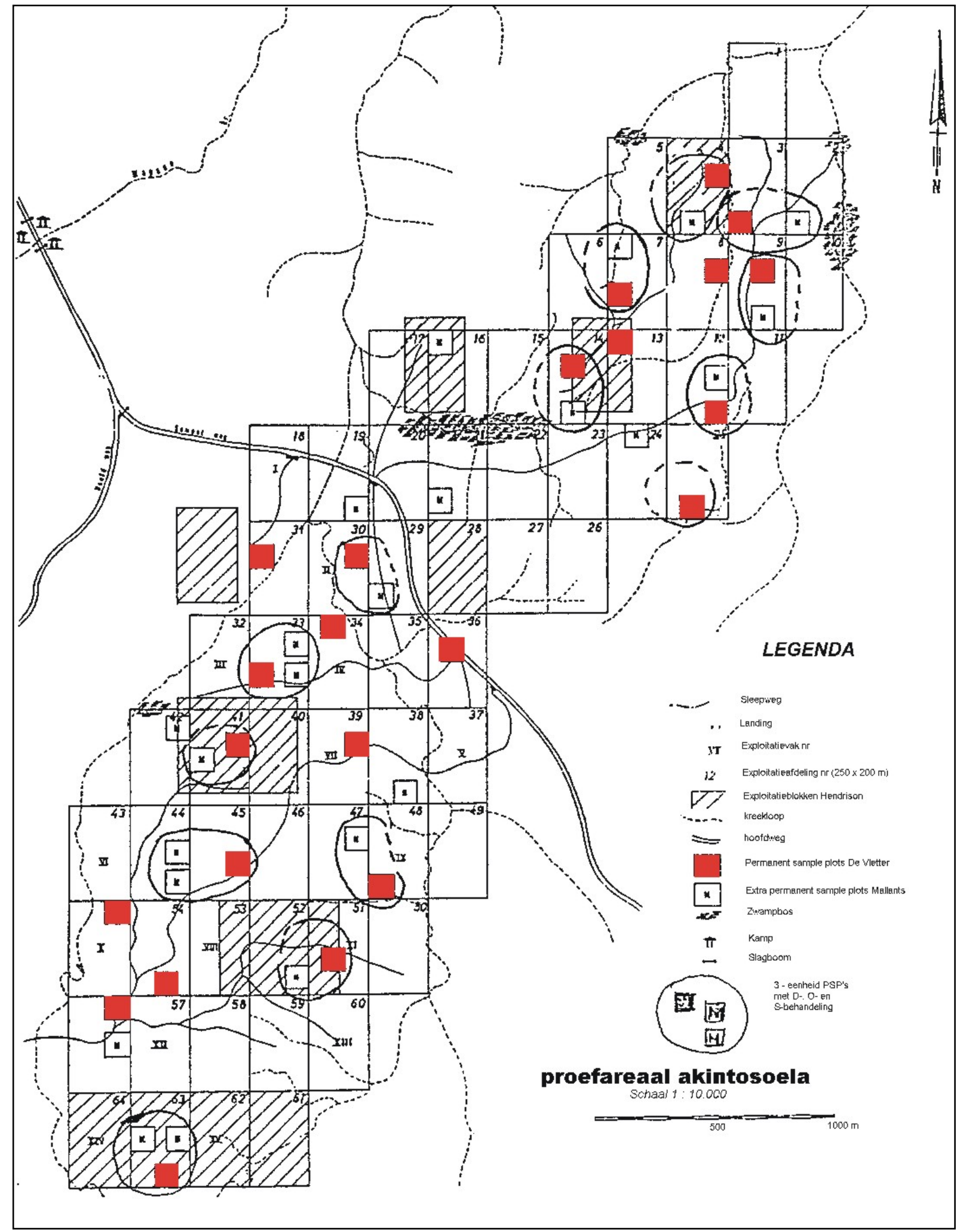

Figure 1: Location Experimental plots Mapane (Legend top to bottom: logging road, landing, exploitation compartment $\mathrm{nr}$, exploitation department $\mathrm{nr}(250 \times 200 \mathrm{~m})$, exploitation patches of Hendrison, creek, main road, Permanent sample plots De Vletter, Extra permanent sample plots Mellants, Zwamp-forest, Camp, road barrier, inside the circle there is a three unity of PSP's with D-, 0 - and S-treatment).

This cleaning-rate is classified in the table with a 0-degree (not cleaned), and A-degree (very light cleaning) up to a G-degree (very heavy cleaning). 
Every experimental plot is 1 ha in size, in a square of $100 \times 100 \mathrm{~m}$.

Every experimental plot is subdivided in 25 subplots of $20 \times 20 \mathrm{~m}$ (see Figure 2).

Table 1: Experimental plot data Mapane

\begin{tabular}{|c|c|c|c|c|c|}
\hline Plotnr & Location & $\begin{array}{l}\text { Experiment Hen- } \\
\text { drison } \\
\text { harvest }\end{array}$ & Cleaning & $\begin{array}{c}\text { Minimal } \\
\text { diameter } \\
\text { cleaning }(\mathrm{cm})\end{array}$ & Cleaning-rate \\
\hline $3-7$ & North & 0 & Yes & 40 & $\mathrm{D}$ \\
\hline $4-4$ & North & $\mathrm{C}$ & Yes & 30 & $\mathrm{~F}$ \\
\hline $7-6$ & North & 0 & Yes & 65 & A \\
\hline $8-4$ & North & 0 & Yes & 25 & G \\
\hline $9-4$ & North & 0 & Yes & 65 & A \\
\hline $12-8$ & North & 0 & Yes & 40 & $\mathrm{D}$ \\
\hline $13-2$ & North & C & Yes & 35 & $E$ \\
\hline $14-3$ & North & $1 / 2 \mathrm{C}$ and $1 / 20$ & Yes & 30 & $\mathrm{~F}$ \\
\hline $25-7$ & North & 0 & Yes & 35 & $E$ \\
\hline $30-4$ & South & 0 & Yes & 45 & C \\
\hline $31-3$ & South & 0 & No & & 0 \\
\hline $33-6$ & South & 0 & Yes & 45 & C \\
\hline $34-2$ & South & 0 & No & & 0 \\
\hline $36-3$ & $1 / 2$ North and $1 / 2$ South & 0 & No & & 0 \\
\hline $39-4$ & South & 0 & No & & 0 \\
\hline $41-4$ & South & $\mathrm{T}$ & Yes & 25 & G \\
\hline $45-6$ & South & 0 & Yes & 25 & G \\
\hline $48-7$ & South & 0 & Yes & 50 & B \\
\hline $51-6$ & South & $1 / 2 \mathrm{~T}$ and $1 / 20$ & Yes & 30 & $\mathrm{~F}$ \\
\hline $54-8$ & South & 0 & No & & 0 \\
\hline $55-1$ & South & 0 & No & & 0 \\
\hline $56-1$ & South & 0 & No & & 0 \\
\hline $63-8$ & South & $\mathrm{C}$ & Yes & 40 & $\mathrm{D}$ \\
\hline
\end{tabular}

\section{Measurements in the experimental plots}

In the experimental plots the following data are recorded of all trees above $25 \mathrm{~cm}$ in diameter, either by measurement or otherwise determined:

- Plot- or experimental plot number

- Subplot number

- $\quad$ Tree number in $1981 / 82$

- $\quad$ Tree number in $1997 / 98$

- $\quad$ Timber species in 1981/82

- Timber species in 1997/98

- Celos-timber species code in 1997/98

- Girth in mm in 1997/98

- Height on which girth is measured in 1997/98

- Remarks on damage, death, logging, liana, not retrieving of a 1981-tree, girdling, stem quality, (stem) fork, etc

This series of data concerns the so-called PSP-series (Permanent Sample Plots).

Apart from these, on three random chosen subplots (random chosen out of the 9 central subplots) also trees of 5 to $25 \mathrm{~cm}$ were inventoried. This is the PCQ-series (Permanent Central Quadrant). The recorded data are in principle the same, with own PCQ tree-numbers, and often the PSP-tree numbers as well. 


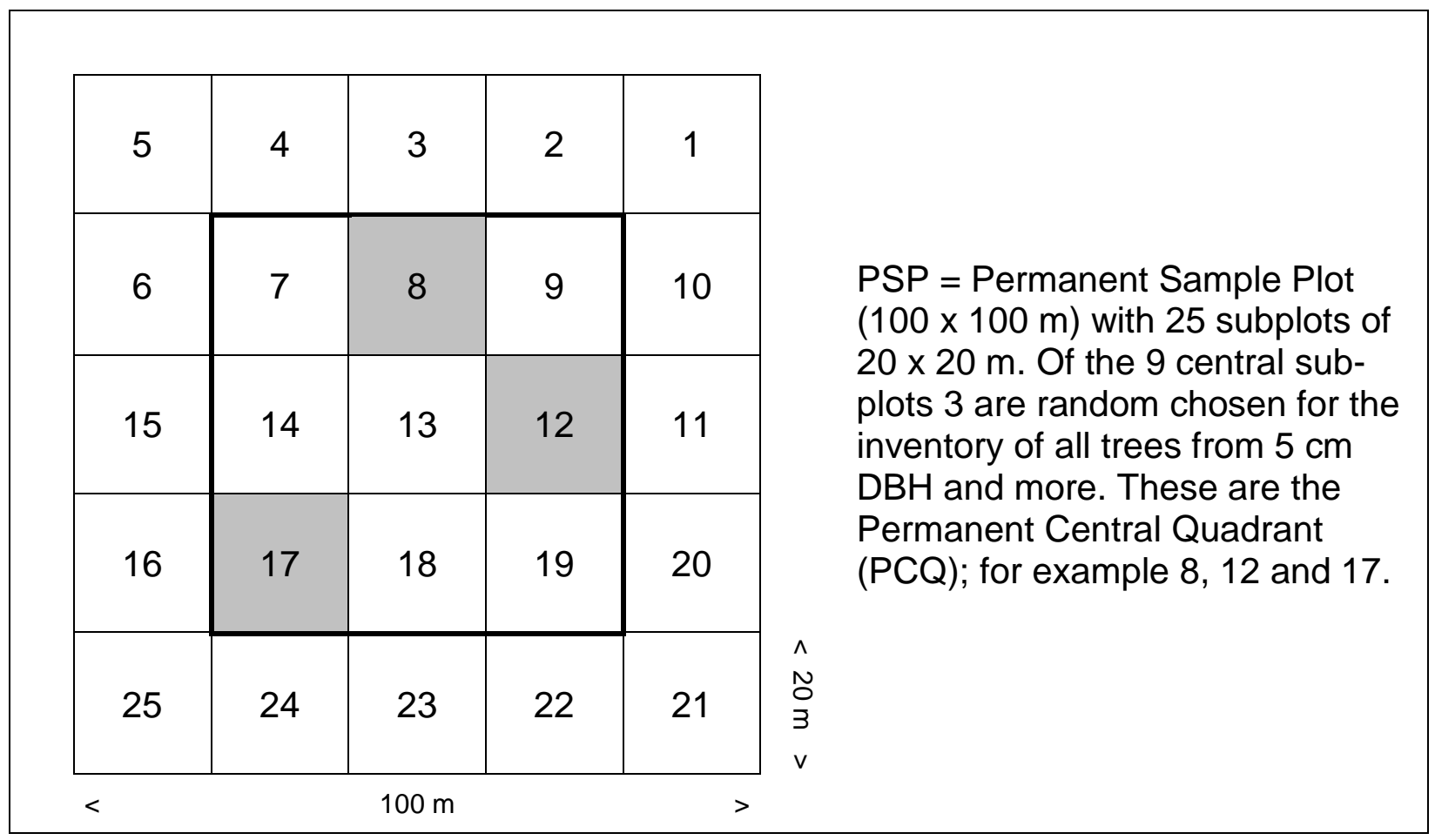

Figure 2: Experimental plot classification; 1 PSP, with 25 subplots and 3 PCQ's

Sometimes the original data file holds only the numbers of the PSP-trees, as sort of orientation point. In some cases the recorded data are also included. These are not always identical to the data of the tree with the same number in the PSP-file.

According to Bus and Laumans (1997b), the location of the subplots is not very accurately measured. Quotation of page 11 "De afmetingen van de oude subplots wijken regelmatig af van de bedoelde 20x20 meter; het opnieuw uitzetten van de subplots zonder rekening te houden met de positie van de oude grenspalen zou in veel gevallen niet dezelfde subplots als in 1981 opleveren." (English: The dimensions of the old subplots regularly differ from the meant 20x20 meters. Without considering the position of the old border poles, in many cases the placement of the new subplots would not give the same subplots as in 1981). To determine the data per area unit the (sub)-plot areas are presumed fixed and in accordance with the experimental plot design. This approach was necessary due to a lack of better information. 


\section{Problem definition and research questions}

Originally, a series of treatments was foreseen in the forest with a CSS-treatment (Celos Silvicultural system), with the goal to produce a larger quantity of Commercial Timber Species (CTS) per timeframe and area in comparison to an untreated forest. An effect should be visible, even when only one-step in the CSS-treatment was carried out, at least when the CSSsystem can meet its pretensions. In addition, on part of the experimental plots a "controlled harvest", "traditional harvest" or "not harvested" was performed according the CHS (Celos Harvesting System) standards. The idea behind the CHS is that this will lead to less damage, so less mortality, and thus more growth.

That is why the available material in the Mapane-experiment should proof a higher increment of CTS in the treated experimental plots versus the non-treated experimental plots. Possibly this increment varies per cleaning-rate and harvesting method, a reclassification of these cleaning-rates to a smaller number of classes could be necessary. An effect with 8 degrees of freedom, at only 23 cases, most likely will give problems for the possibility in distinction of several statistical tests.

No wood volumes were determined in the experimental plots and there are no distinguishing relationships between the measured variables and volume. We have to use a characteristic with a large correlation to the volume per ha. The most obvious characteristic is the basal area of the experimental plot per ha, this is the cumulative tree basal area. In short this will be called the basal area per ha. All results will also be presented with a volume-indication, based on an "out-place" estimator.

The research question can be split in several sub-questions:

1. Is the basal area ingrowth (recruitment over specified diameter) of Commercial Timber Species (CTS) in the PCQ's larger at the treated experimental plots than at the untreated experimental plots, for the diameter-limit of $5 \mathrm{~cm}$ ?

2. Is the basal area ingrowth of Commercial Timber Species (CTS) in the PSP's larger at treated experimental plots than at untreated experimental plots, for the diameter-limit of 25 $\mathrm{cm}$ ?

3. Is the basal area increment of Commercial Timber Species (CTS) in treated experimental plots larger than for the untreated experimental plots?

4. Is it possible to make a better classification of the treatments than "treated - untreated" or the classification in cleaning-rates? The possible development of this classification, in advance will be called the cleaning-class.

Some other aspects concerning the forest dynamics, which are not directly derived from the problem definition, are investigated.

5. Is mortality influenced by the treatment?

6. Is the damage to trees influenced by the treatment? 


\section{Methods}

At first, the data is revised at tree level, after which the data is aggregated at experimental plot level. Using SPSS for Windows - Release 11.5.0 the experimental plot data is analysed to see whether the research questions could be answered with yes. Next to this, the diameter class distribution is mapped and some forest dynamics are described.

\section{The modification of the data}

\section{Timber species}

The names of the timber species are far from identical in the two inventories. The name of the last inventory was chosen in case of two different names. The names of 1981/82 were maintained for trees not occurring in 1997/98. In total 842 spelling-variations occurred of 267 timber species. In consultation with Reitze de Graaf an unambiguous species list is determined, slightly deviating from the conventional. For example "Hoogland baboen" is indicated as "Baboen hgl" and "Kleinbladige rode kabbes" as "Kabbes rode kl.bl.". When it was impossible to determine whether it were spelling-variations or different species both names were listed as separate species, that is why there is "Fijnbladige rode kabbes" next to "Kleinbladige rode kabbes", possibly these are the same tree species. This list is inserted as Appendix I, including the frequencies. The timber class (CTS or NCTS, Commercial- or Non Commercial Timber Species) was determined with the help of the CELOS-timber code list as well.

\section{Diameter at Breast Height}

The DBH is derived out of the girth measurement in the usual way, when the measurement height used to be $1.30 \mathrm{~m}$ :

$$
D B H=\frac{\text { Girth }}{\pi * 10} \text { (with Girth in mm and } D B H \text { in } \mathrm{cm} \text { ) }
$$

At a measurement- or reference-height (Rh) above $1.30 \mathrm{~m}$ (for example in the case of buttresses), we worked with a rectilinear taper function derived from a hypothetical height of 30 $\mathrm{m}$ through the reference height $(\mathrm{Rh})$ :

$D B H=\frac{\operatorname{Girth}(R h)}{\pi * 10} \times \frac{30-1.30}{30-R h}$ (with Girth in $\mathrm{mm}, R h$ in $\mathrm{m}$ and $D B H$ in $\mathrm{cm}$ )

Basal area of the trees

The basal area of the trees is calculated out of the diameter in the usual way:

$$
g_{1,30}=0.25 * \pi * D B H^{2} \quad \text { (with } D B H \text { in } \mathrm{m} \text { and } g_{1.30} \text { in } \mathrm{m}^{2} \text { ) }
$$

Tree volume

The tree volume is estimated with the out-place estimator, namely the merchantable volume tariff of Jonkers (1987, Appendix VI) for the Kabo and Tonka district. The equation is as follows:

$$
v=a+b^{*} D B H^{2} \quad \text { (with } D B H \text { in } c \text { m and } v \text { in } \mathrm{m}^{3} \text { ) }
$$

Jonkers has general and species specific constant-values for 12 CTS, of which 10 occur in the Mapane-plots. The list of CTS of Jonkers is smaller than the CELOS-list nowadays. The decision was made to use the rate of the described tree species of Jonkers and his general CTSrate for all the additional tree species, both for CTS and NCTS. See below for the constantvalues. 
Table 2: Volume tariff constants Jonkers

\begin{tabular}{|l|c|c|}
\hline Tree species & a & B \\
\hline CTS - general & -0.2335 & 0.001125 \\
\hline Goebaja & -0.0239 & 0.001040 \\
Sali rode & -0.0836 & 0.000759 \\
Tingimoni sali & -0.2013 & 0.000943 \\
Kopi & -0.3153 & 0.001020 \\
Basralokus & -0.3232 & 0.001208 \\
Krapa & -0.1065 & 0.000812 \\
Baboen hgl & -0.2169 & 0.001199 \\
Riemhout zw & -0.3481 & 0.001189 \\
Gronfolo hgl & -0.4308 & 0.001412 \\
Gronfolo bergi & -0.1486 & 0.001213 \\
\hline
\end{tabular}

Annual increment in diameter

The annual increment in diameter of the residuals (trees that lived in both inventories of 1982 and 1997) is determined as follows:

$$
i_{d}=\frac{D B H 97-D B H 81}{16} \text { in } \mathrm{cm} / \mathrm{yr}
$$

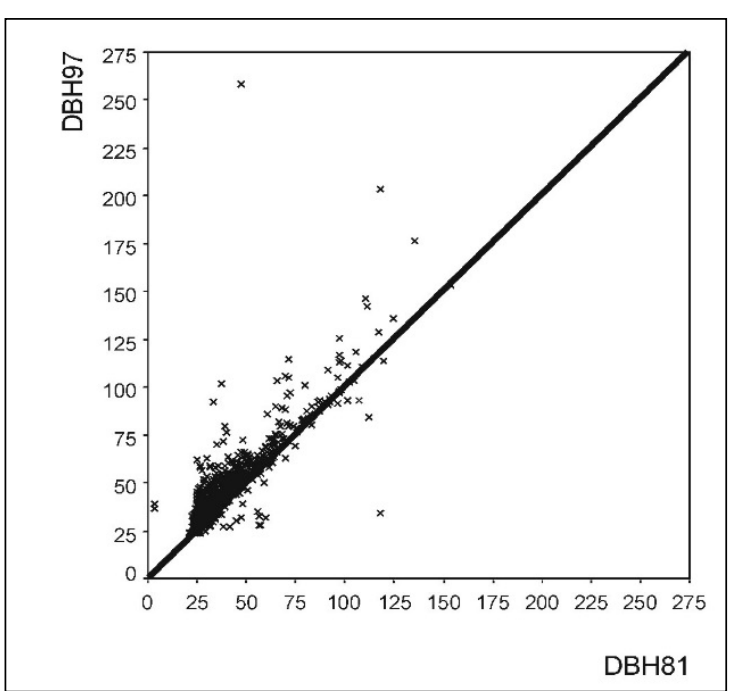

Sometimes this calculation leads to the question whether it is actually the same tree. In Figure 3 $D B H 97$ is plotted against $D B H 81$. Due to "normal” measurement mistakes and real negative growth (a tree can shrink due to loss of fluids) values directly below the diagonal are likely. In the shown figure, however, there are many large peak-values, in which case you can evidently speak of either an incorrect $D B H 81$ or an incorrect $D B H 97$. In those cases it was determined to treat these as two distinctive trees, one tree measured in 1981 statistically disappears (gone with unknown cause) and appears as a new, not previously measured tree in 1997.

Figure 3: Relation DBH81 and DBH97

$\underline{\text { Remarks }}$

There appear many (1515) different remarks, which can be traced back to:

1 Mutations since previous inventory, for example:

- $\quad$ niet gevonden $=$ not found $(29 x)$

- $\quad$ niet gevoden $=$ not fond $(7 \mathrm{x})$

- $\quad$ niet gevonden $=$ not found $(381 x)$

- $\quad$ Niet gevonden $=$ Not found $(40 \mathrm{x})$

2 Experimental plot maintenance:

- NB: new 115 could also be old 119! (1x)

- NB: new 118 could also be old 119! (1x)

- Long ladder measurement. White no. 28 (1x)

3 Damage or mortality

- damaged and hollow (1x) 
- damaged and many lianas $(1 \mathrm{x})$

- E, trunk rotten $(1 \mathrm{x})$

- E, trunk until $20 \mathrm{~m}$ on I site rotten (1x)

- half of twins, other half is dead (1x)

4 Other remarks

- liana in it (16x)

- liana on stem, termites nest $(1 \mathrm{x})$

5 Combinations

- Old measurements limitedly usable. Hollow at 8-10 m, ants (1x)

- NB; old measurement tree! Crooked; old number looks like 129 (1x)

- $\quad \mathrm{NB} ; 2$ 2nd tree with old no 26 in subplot 5 death standing (1x)

- not found/ valuable wood: roots dugged out? (1x)

- without top, lianas in it, bees nest in it

These remarks are processed towards a type "tree mutation" and a type "damage class". Nothing was done with a number of remarks out of the category "experimental plot maintenance" and "others". For example the remark "not found/ valuable wood: roots dugged out?" was translated towards the conclusion that the tree was cut down. An option with "roots dugged out" could be that a Granmankapasi uprooted the tree looking for a bees nest in the roots; in this case the conclusion should be "death". However the combination with "not found/ valuable wood" and the fact that it was Snakewood (Brosimum guianense) pleads for "cut down (felled)" or better "cleared", but that is not a distinct separate category.

Tree mutations

The following classification was used for the mutations in the appearance of both inventories.

\section{Table 3: Tree mutation code}

\begin{tabular}{|c|c|c|}
\hline \multicolumn{2}{|c|}{ Mutation type } & \multirow{2}{*}{$\begin{array}{l}\text { Explanation } \\
\text { Measured in both } 1981 \text { and } 1997\end{array}$} \\
\hline & Residual & \\
\hline 1 & Cut down & Measured in 1981, in 1997 remark: cut down \\
\hline 2 & Dead & Measured in 1981, in 1997 remark: dead \\
\hline 3 & Dead due to girdling & Measured in 1981, cleaned in 1984, dead in 1997 \\
\hline 4 & Not found & Measured in 1981, not in 1997, sometimes with remark: not found \\
\hline 5 & Ingrower PSP & Not measured in 1981, measured in 1997 (in PSP-inventory) \\
\hline 6 & $\begin{array}{l}\text { Residual in PCQ/ ingrower } \\
\text { PSP }\end{array}$ & $\begin{array}{l}\text { Measured in } 1981 \text { in PCQ-inventory, in } 1997 \text { above measuring-limit of } 25 \\
\mathrm{~cm} \text { in diameter }\end{array}$ \\
\hline 7 & Other tree? & $\begin{array}{l}\text { Measured in both inventories, however obviously not the same tree, } \\
\text { mostly determined at the inventory }\end{array}$ \\
\hline 8 & Ingrower PCQ & Not present in 1981, present and measured in 1997 \\
\hline & Cleaned in 1984 & $\begin{array}{l}\text { Trees in the mutation types } 1,2 \text {, and } 4 \text { are later classified in type } 9 \text {, if it } \\
\text { concerns a non-commercial timber species from } 1981 \text { thicker than the } \\
\text { cleaning-diameter for the specific experimental plot. Mutation type } 3 \text { is } \\
\text { added completely to type } 9 \text {. }\end{array}$ \\
\hline
\end{tabular}

\section{Damage classes}

A classification is made on the ground of the collection "remarks". The following damage categories have been chosen:

1. no damage

2. hollow or rotten

3. broken off

4. other damage

5. girdled, but still alive 


\section{Results}

\section{Basal area ingrowth}

The effects of the cleaning-rate, Hendrison-research and the North-South factor on the ingrowth of the basal area (above $5 \mathrm{~cm}$ ) of the CTS-species have been studied using ANOVA. The NorthSouth effect is significant at a significance level of $10 \%$, the harvest effect of Hendrison is very significant. The difference between the traditional and controlled harvest clearly is in the advantage of the controlled harvesting. The interactions cannot be estimated due to a lack of degrees of freedom. The effect of the cleaning-rates is very significant. Within the cleaning-rates, the untreated does not seem to differ from the A-, B-, and C-rates. In addition to this the D-, E, F- and G-rates do not statistically differ from one another, but this group does differ significantly from the previous group.

In Table 4, Table 5 and Figure 4 the results of an ANOVA with the effects "Cleaning-rate" and "Hendrison-research" for the basal area ingrowth (above $5 \mathrm{~cm}$ ) of the CTS-species are given.

Table 4: Effects in ANOVA with ingrowth CTS (Gingrowth-CTS)

\begin{tabular}{|ll|l|r|}
\hline Effect & & \multicolumn{1}{|c|}{ Explanation } & Number \\
\hline Cleaning-rate & O & No cleaning & 7 \\
& A & A-rate & 2 \\
& B & B-rate & 1 \\
& C & C-rate & 2 \\
& D & D-rate & 3 \\
& E & E-rate & 2 \\
& F & F-rate & 3 \\
& G & G-rate & 3 \\
Hendrison & O & No harvest & 17 \\
& C & Controlled harvest & 2 \\
& T & Traditional harvest & 4 \\
& 0 & South & 14 \\
& 1 & North & 9 \\
\hline
\end{tabular}

Table 5: ANOVA Effect of cleaning-rates (CR) and Hendrison (HEN) on ingrowth CTS (Ging-CTS)

\begin{tabular}{|l|r|r|r|r|r|}
\hline Source & $\begin{array}{c}\text { Type III Sum } \\
\text { of Squares }\end{array}$ & df & Mean Square & F & Sig. \\
\hline Corrected Model & 7.751 & 12 & .646 & 20.794 & .000 \\
Intercept & 9.154 & 1 & 9.154 & 294.697 & .000 \\
CR & 1.829 & 7 & .261 & 8.412 & .002 \\
HEN & .621 & 2 & .311 & 9.997 & .004 \\
NS & .104 & 1 & .104 & 3.362 & .097 \\
Error & .311 & 10 & .031 & & \\
Total & 19.065 & 23 & & & \\
Corrected Total & 8.061 & 22 & & & \\
$\mathrm{R}^{2}=.961$ (Adjusted $\left.\mathrm{R}^{2}=.915\right)$
\end{tabular}

It was determined to continue working with cleaning-classes. The group with an A-, B-, en Crate are indicated by an $\mathrm{N}$ (= not or hardly cleaned). The D- up to G-rate is merged to a group $\mathrm{H}$ (heavily cleaned). 


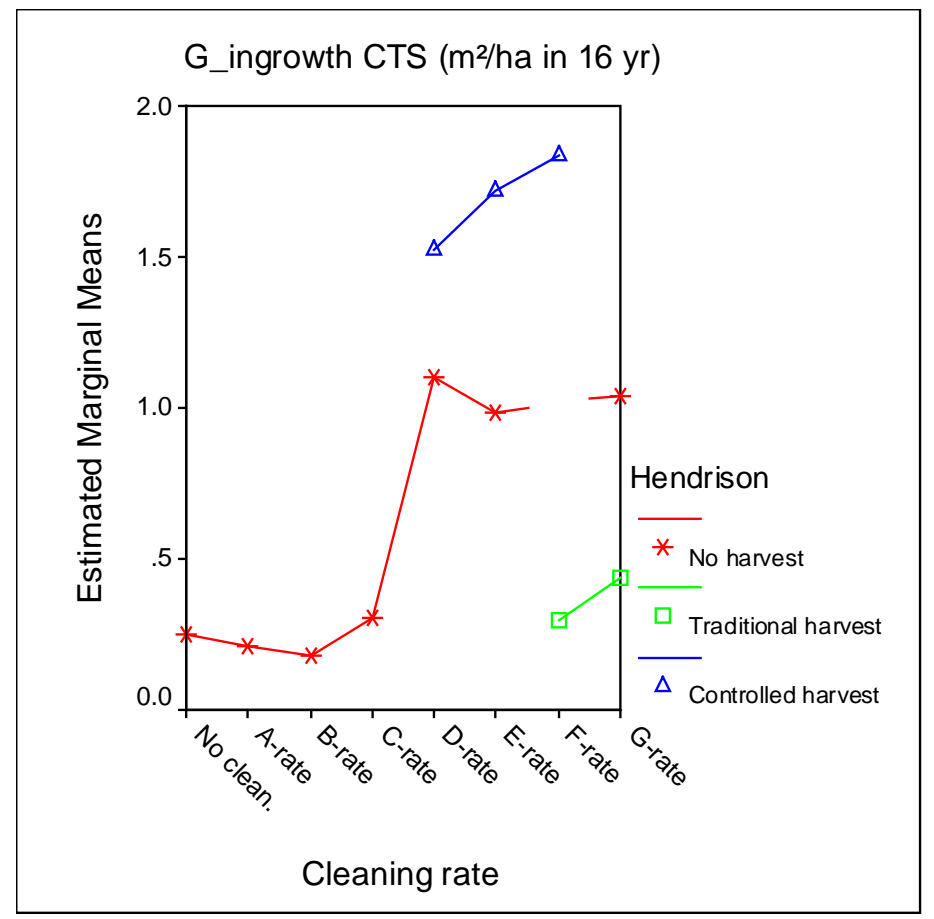

Figure 4: Effects of cleaning-rates on the basal area ingrowth above $5 \mathrm{~cm}$ (CTS)

After a number of comparable tests with other random samples, it was decided to use this classification (the effect "cleaning-class" with 2 levels) as the most distinctive, see Table 4 for the revised effects per experimental plot.

Table 6: Revised experimental plot data Mapane

\begin{tabular}{|c|c|c|c|c|c|c|}
\hline Plotnr. & Location & Hendrison & $\begin{array}{c}\text { Cleaning- } \\
\text { rate }\end{array}$ & $\begin{array}{c}\text { Gpsp before } \\
\text { cleaning } \\
\left(\mathrm{m}^{2} / \mathrm{ha}\right)\end{array}$ & $\begin{array}{c}\text { Gpsp after } \\
\text { cleaning } \\
\left(\mathrm{m}^{2} / \mathrm{ha}\right)\end{array}$ & $\begin{array}{c}\text { Cleaning- } \\
\text { classes }\end{array}$ \\
\hline $3-7$ & North & 0 & $\mathrm{D}$ & 16.6 & 13.6 & $\mathrm{H}$ \\
\hline $4-4$ & North & C & $\mathrm{F}$ & 19.0 & 9.0 & $\mathrm{H}$ \\
\hline $7-6$ & North & 0 & A & 18.1 & 17.0 & $\mathrm{~N}$ \\
\hline $8-4$ & North & 0 & G & 19.4 & 8.1 & $\mathrm{H}$ \\
\hline $9-4$ & North & 0 & A & 21.3 & 18.2 & $\mathrm{~N}$ \\
\hline $12-8$ & North & 0 & $\mathrm{D}$ & 18.4 & 10.9 & $\mathrm{H}$ \\
\hline $13-2$ & North & C & $E$ & 21.6 & 11.2 & $\mathrm{H}$ \\
\hline $14-3$ & North & $C+0$ & $F$ & 16.5 & 7.5 & $\mathrm{H}$ \\
\hline $25-7$ & North & 0 & $E$ & 23.3 & 12.8 & $\mathrm{H}$ \\
\hline $30-4$ & South & 0 & $\mathrm{C}$ & 20.1 & 11.2 & $\mathrm{~N}$ \\
\hline $31-3$ & South & 0 & 0 & 22.3 & 22.3 & $\mathrm{~N}$ \\
\hline $33-6$ & South & 0 & C & 15.5 & 10.8 & $\mathrm{~N}$ \\
\hline $34-2$ & South & 0 & 0 & 17.5 & 17.5 & $\mathrm{~N}$ \\
\hline $36-3$ & $N+S$ & 0 & 0 & 17.1 & 17.1 & $\mathrm{~N}$ \\
\hline $39-4$ & South & 0 & 0 & 15.6 & 15.6 & $\mathrm{~N}$ \\
\hline $41-4$ & South & $\mathrm{T}$ & G & 23.6 & 8.9 & $\mathrm{H}$ \\
\hline $45-6$ & South & 0 & G & 17.8 & 7.8 & $\mathrm{H}$ \\
\hline $48-7$ & South & 0 & B & 13.0 & 10.4 & $\mathrm{~N}$ \\
\hline $51-6$ & South & $\mathrm{T}+0$ & $F$ & 17.3 & 8.0 & $\mathrm{H}$ \\
\hline $54-8$ & South & 0 & 0 & 15.2 & 15.2 & $\mathrm{~N}$ \\
\hline $55-1$ & South & 0 & 0 & 16.0 & 16.0 & $\mathrm{~N}$ \\
\hline $56-1$ & South & 0 & 0 & 24.4 & 24.4 & $\mathrm{~N}$ \\
\hline $63-8$ & South & C & D & 21.4 & 15.3 & $\mathrm{H}$ \\
\hline
\end{tabular}


Figure 4 suggest an increase of the basal area ingrowth in CTS above $5 \mathrm{~cm}$ due to (middle) heavy cleaning, even though the evidence is paper-thin. This effect is quite enlarged when Hendrison's method of "controlled harvest” is applied. The effect seems completely eliminated when a "traditional harvest" is carried out. The ANOVA was repeated with the cleaning-class rather than the cleaning-rate as you can see in Table 7. The North-South effect no longer seems to be significant, but there obviously still is a intermingling between the Hendrison-effect and the North-South effect.

Table 7: ANOVA with the effects Cleaning-class (CC), North-South (NS) and Hendrison (HEN) at G-ingrowth CTS

\begin{tabular}{|c|c|c|c|c|c|}
\hline Source & $\begin{array}{l}\text { Type III Sum } \\
\text { of Squares }\end{array}$ & df & Mean Square & $\mathbf{F}$ & Sig. \\
\hline Corrected Model & 7.667 & 6 & 1.278 & 51.865 & .000 \\
\hline Intercept & 9.043 & 1 & 9.043 & 367.023 & .000 \\
\hline $\mathrm{CC}$ & 1.761 & 1 & 1.761 & 71.495 & .000 \\
\hline HEN & 1.492 & 2 & .746 & 30.275 & .000 \\
\hline NS & .004 & 1 & .004 & .157 & .697 \\
\hline$C C * N S$ & .027 & 1 & .027 & 1.103 & .309 \\
\hline $\mathrm{HEN}$ * NS & .116 & 1 & .116 & 4.715 & .045 \\
\hline Error & .394 & 16 & .025 & & \\
\hline Total & 19.065 & 23 & & & \\
\hline Corrected Total & 8.061 & 22 & & & \\
\hline
\end{tabular}

In Table 8 the eventual ANOVA data is listed. Without the HEN-NS interaction the $\mathrm{R}^{2}$ slightly decreases, but remains very high.

Table 8: ANOVA G-ingrowth CTS > 5cm with CC (cleaning-class)

\begin{tabular}{|l|r|r|r|r|r|}
\hline Source & $\begin{array}{c}\text { Type III Sum } \\
\text { of Squares }\end{array}$ & Df & Mean Square & \multicolumn{1}{c|}{ F } & Sig. \\
\hline Corrected Model & 7.547 & 3 & 2.516 & 92.961 & .000 \\
Intercept & 8.402 & 1 & 8.402 & 310.455 & .000 \\
CC & 2.289 & 1 & 2.289 & 84.596 & .000 \\
HEN (C + T) & 2.617 & 2 & 1.308 & 48.349 & .000 \\
Error & .514 & 19 & .027 & & \\
Total & 19.065 & 23 & & & \\
Corrected Total & 8.061 & 22 & & & \\
$\mathrm{R}^{2}=.936$ (Adjusted $\left.\mathrm{R}^{2}=.926\right)$
\end{tabular}

Instead of representing this result as an ANOVA model, it can also be represented by a linear regression model, as follows:

$$
G_{\text {ing-WHS }}=0.248+0.805 * C C+0.677 * C-0.687 * T \quad\left(R^{2} a d j=0.926\right)
$$

There is a large significant effect of the cleaning-class at the basal area ingrowth of the CTS above $5 \mathrm{~cm}$, this is almost 4 times as large $\left(1.053\right.$ instead of $0.248 \mathrm{~m}^{2} /$ ha in the timeframe of 16 years). Under controlled harvest this is 1.731 and with traditional harvest $0.376 \mathrm{~m}^{2} / \mathrm{ha}$. For the values and significance of the remaining basal area ingrowth numbers see Table 9. 
Table 9: Average basal area ingrowth ( $\mathrm{m}^{2} / \mathrm{ha}$ over $\left.16 \mathrm{yr}\right)$

\begin{tabular}{|l|r|r|r|r|r|r|}
\hline Cleaning-class/Harvest & \multicolumn{1}{|c|}{ CTS $>$ 5 } & CTS > 25 & NCTS > 5 & NCTS > 25 & \multicolumn{1}{c|}{ Tot > 5 } & Tot > 25 \\
\hline N No harvest & 0.25 & 0.95 & 2.47 & 3.18 & 2.32 & 4.08 \\
H No harvest & 1.05 & 0.95 & 2.47 & 4.36 & 4.14 & 5.06 \\
$\quad$ Controlled harvest & 1.73 & 1.69 & 4.94 & 4.36 & 6.67 & 6.64 \\
Traditional harvest & 0.37 & 0.95 & 4.75 & 4.36 & 4.14 & 5.06 \\
\hline $\mathrm{R}^{2}$ adj (in LR-model) & 0.93 & 0.35 & 0.35 & 0.24 & 0.52 & 0.38 \\
\hline
\end{tabular}

Notice: if the values differ, these are significantly different $(\alpha=0.05)$.

The cleaning and the method of harvesting apparently largely and positively influence the basal area ingrowth of the Commercial Timber Species (CTS) in the lower diameter classes. We can interpret this as a high rejuvenation for the CTS within the timeframe of 16 years, due to the $\mathrm{H}$ (heavy)-cleaning treatment and the controlled harvest. For the NCTS this holds a lot less and solitary for the cleaning, there is no harvest effect. Without (or with light) cleaning and without harvest $11 \%$ of the rejuvenation ingrowth exists of CTS, with H-cleaning treatment this will be $20 \%$ and when we also perform a controlled harvest it will be $29 \%$. In absolute values, it is a fourfold (from 0.25 to 1.05) in the case of heavy cleaning and a sevenfold (from 0.25 to 1.73) of the rejuvenination ingrowth when a controlled harvest is performed additionally. The rejuvenation ingrowth is measured in $\mathrm{m}^{2} /$ ha basal area ingrowth over the $5 \mathrm{~cm}$ measurement limit in 16 years.

The development speed in the diameter class 5-25 cm towards exceeding the $25 \mathrm{~cm}$ changes less spectacular due to the treatment. The cleaning itself does not influence the result. However, in combination with the controlled harvest the ingrowth above the $25 \mathrm{~cm}$ of CTS has increased with $78 \%$, while the relative CTS-share increases slightly from $18 \%$ to $23 \%$. This share would decrease slightly from $18 \%$ to $13 \%$ without controlled harvest.

\section{Basal area increment}

Another possibility to look at the experiment effects could be an analysis of the increment of the basal area on the existing trees. However, per definition the increment of the basal area depends on the existing basal area per class, after all it can only grow additionally when there was already something present. There are two possibilities to consider this in the model.

1. Use the relative basal area increment: $I G_{r e l}=I G / G$

2. Use a MLR-model: $I G=a_{0}+a_{1} * G+a_{2} * C C$

The differences in (relative) increment of the basal area seems not explained by the cleaningclass, there does seem to be a slight significant difference between North and South. Found is the following:

$$
I G_{W H S}=0.137+0.048 * G_{81}+0.252 * N S \quad\left(R^{2} a d j=0.302\right) \quad\left(\text { in } \mathrm{m}^{2} / \text { ha per } 16 \mathrm{yr}\right)
$$

However, this North-South effect was already assumed in the beginning of this experiment. This pre-assumption thus is validated, apart from the fact that under equal circumstances the CTS grow $0.015 \mathrm{~m}^{2} / \mathrm{ha} / \mathrm{yr}$ more in the north than in the south (app. 15\% more).

\section{Dynamics 1981-1997}

In Table 10, Table 11 and Table 12 the dynamics are listed of respectively the average basal area, the average stem number and the average volume set up over the 23 remeasured experimental plots for the period 1981/82 until 1997/98. The significance in the stemnumber mutations has not been investigated, because this is not interesting in relation to the original research question. The significance of the volume set up cannot be determined due to the use of an outplace element with unknown purity and variance. 
Table 10: Basal area dynamics in $\mathrm{m}^{2} / \mathrm{ha} 1981-1997$

\begin{tabular}{|c|c|c|c|c|c|c|c|c|c|c|c|c|c|c|c|c|c|c|}
\hline \multirow{5}{*}{$\begin{array}{c}\text { Mapane } \\
1981-1997\end{array}$} & \multirow{2}{*}{\multicolumn{6}{|c|}{$\frac{\text { PCQ random sample } d<25 \mathrm{~cm}}{\text { Cleaning }}$}} & \multirow{2}{*}{\multicolumn{6}{|c|}{$\begin{array}{c}\text { PSP - inventory: } d>=25 \mathrm{~cm} \\
\text { Cleaning }\end{array}$}} & \multirow{2}{*}{\multicolumn{6}{|c|}{$\begin{array}{c}\text { Total } \\
\text { Cleaning }\end{array}$}} \\
\hline & & & & & & & & & & & & & & & & & & \\
\hline & \multicolumn{3}{|c|}{ none/light } & \multicolumn{3}{|c|}{ heavy } & \multicolumn{3}{|c|}{ none/light } & \multicolumn{3}{|c|}{ heavy } & \multicolumn{3}{|c|}{ none/light } & \multicolumn{3}{|c|}{ heavy } \\
\hline & \multicolumn{3}{|c|}{ Timberclass } & \multicolumn{3}{|c|}{ Timberclass } & \multicolumn{3}{|c|}{ Timberclass } & \multicolumn{3}{|c|}{ Timberclass } & \multicolumn{3}{|c|}{ Timberclass } & \multicolumn{3}{|c|}{ Timberclass } \\
\hline & NCTS & CTS & Тот & NCTS & CTS & Тот & NCTS & CTS & Тот & NCTS & CTS & Тот & NCTS & CTS & Тот & NCTS & CTS & Тот \\
\hline 1981-82 & 6.9 & 1.6 & 8.5 & 4.8 & 1.3 & 6.1 & 12.8 & 5.2 & 18.0 & 13.4 & 6.2 & 19.5 & 19.7 & 6.8 & 26.5 & 18.2 & 7.5 & 25.6 \\
\hline Cleaning ${ }^{1)}$ & & & & & & & -1.7 & 0.0 & -1.7 & -9.3 & 0.0 & -9.3 & 0.0 & 0.0 & 0.0 & 0.0 & 0.0 & 0.0 \\
\hline After cleaning ${ }^{1)}$ & 6.9 & 1.6 & 8.5 & 4.8 & 1.3 & 6.1 & 11.1 & 5.2 & 16.3 & 4.1 & 6.2 & 10.3 & 18.0 & 6.8 & 24.8 & 8.9 & 7.5 & 16.4 \\
\hline Logging & & & & & & & -0.1 & -0.5 & -0.6 & 0.0 & -0.6 & -0.6 & -0.1 & -0.5 & -0.6 & 0.0 & -0.6 & -0.6 \\
\hline Mortality & -0.7 & -0.1 & -0.8 & -0.4 & -0.1 & -0.5 & -2.2 & -0.6 & -2.7 & -0.3 & -0.9 & -1.1 & -2.9 & -0.7 & -3.6 & -0.7 & -1.0 & -1.6 \\
\hline Disappeared & -2.1 & -0.5 & -2.6 & -1.2 & -0.4 & -1.6 & -2.1 & -1.1 & -3.2 & -0.8 & -2.2 & -3.1 & -4.2 & -1.6 & -5.8 & -2.0 & -2.6 & -4.6 \\
\hline Ingrowth & 2.0 & 0.2 & 2.2 & 4.3 & 1.2 & 5.5 & 3.2 & 0.9 & 4.1 & 4.4 & -1.3 & 5.6 & 2.0 & 0.2 & 2.2 & 4.3 & 1.2 & 5.5 \\
\hline Passing threshold & -1.7 & -0.4 & -2.1 & -1.1 & & -1.6 & & & & & & & & & & & & \\
\hline Increment & 3.5 & 1.0 & 4.5 & 2.8 & 1.1 & 3.8 & 2.2 & 1.1 & 3.2 & 1.1 & 1.2 & 2.3 & 5.6 & 2.0 & 7.7 & 3.9 & 2.3 & 6.2 \\
\hline Statistical mutation & & & & & & & 0.6 & 0.1 & 0.7 & 0.1 & 0.0 & 0.1 & 2.0 & 0.6 & 2.6 & 3.4 & -1.7 & 1.6 \\
\hline $1997-98$ & 7.8 & 1.9 & 9.7 & 9.2 & 2.6 & 11.8 & 12.6 & 5.0 & 17.6 & 8.6 & 5.0 & 13.6 & 20.4 & 6.9 & 27.3 & 17.8 & 7.5 & 25.4 \\
\hline
\end{tabular}

1) The cleaning has been performed in 1984, the situation after the cleaning has been calculated with the data of $1981 / 82$.

From Table 10 (and also Table 11 and Table 12) it obviously shows that other activities took place in all plots outside the cleaning of 1984. In the category "logging CTS" as well as "disappeared" these are considerable amounts, in both basal area and stemnumber. In the category "disappeared" it concerns both CTS and NCTS, possibly that during the treatments also trees were girdled that did not meet the diameter demands. There also appeared to be 10 CTS samples with the mutationcode "death due to girdling". In total, it concerned 119 trees of which it was determined that they died due to girdling. This is not too bad given the difficulty of tree species recognition and the absence of a tree position map. The category "disappeared" however does give serious problems for the interpretation. These trees were not recovered in 1997 and thus it could not be determined whether they were cleaned, dead, or logged. In the case when the trees belonged to the category of the "to be cleaned trees" (so above the valid cleaning diameter for that plot) of the H-treatment, it was automatically assumed that the tree was cleaned. The amount of cleaning presumably is overestimated due to this assumption.

Table 11: Stem number dynamics in number/ha 1981-1997

\begin{tabular}{|c|c|c|c|c|c|c|c|c|c|c|c|c|}
\hline \multirow{5}{*}{$\begin{array}{c}\text { Mapane } \\
1981-1997\end{array}$} & \multicolumn{4}{|c|}{ PCQ random sample $\mathrm{d}<25 \mathrm{~cm}$} & \multicolumn{4}{|c|}{ PSP - inventory: $d>=25 \mathrm{~cm}$} & \multicolumn{4}{|c|}{ Total } \\
\hline & \multicolumn{4}{|c|}{\begin{tabular}{|c|} 
Cleaning \\
\end{tabular}} & \multicolumn{4}{|c|}{ Cleaning } & \multicolumn{4}{|c|}{ Cleaning } \\
\hline & \multicolumn{2}{|c|}{ none/light } & \multicolumn{2}{|c|}{ heavy } & \multicolumn{2}{|c|}{ none/light } & \multicolumn{2}{|l|}{ heavy } & \multicolumn{2}{|c|}{ none/light } & \multicolumn{2}{|l|}{ heavy } \\
\hline & \multicolumn{2}{|c|}{ Timberclass } & \multicolumn{2}{|c|}{ Timberclass } & \multicolumn{2}{|c|}{ Timberclass } & \multicolumn{2}{|c|}{ Timberclass } & \multicolumn{2}{|c|}{ Timberclass } & \multicolumn{2}{|c|}{ Timberclass } \\
\hline & NCTS CTS & Tот & NCTS CTS & Tот & NCTS CTS & Tот & NCTS CTS & Tот & NCTS CTS & Tот & NCTS CTS & Tот \\
\hline 1981-82 & 643162 & 805 & $554 \quad 144$ & 698 & 37 & 124 & $92 \quad 39$ & 132 & $731 \quad 198$ & 929 & $\begin{array}{ll}646 & 183\end{array}$ & 829 \\
\hline Cleaning ${ }^{1)}$ & & & & & -4 & -4 & -48 & -48 & -4 & -4 & -48 & -48 \\
\hline After cleaning ${ }^{1)}$ & $643 \quad 162$ & 805 & $554 \quad 144$ & 698 & 84 & 120 & 45 & 84 & $727 \quad 198$ & 925 & $599 \quad 183$ & 782 \\
\hline Logging & & & & & -1 & -3 & -2 & -2 & $-1 \quad-2$ & -3 & -2 & -2 \\
\hline Mortality & $\begin{array}{ll}-39 & -7\end{array}$ & -46 & -28 & -36 & -13 & -16 & -3 & -8 & $-52-10$ & -62 & -31 & -44 \\
\hline Disappeared & $-147 \quad-33$ & -180 & $-94 \quad-28$ & -122 & -15 & -21 & $-10 \quad-11$ & -21 & $-162-40$ & -201 & -104 & -143 \\
\hline Ingrowth & 35860 & 418 & $579 \quad 174$ & 753 & 40 & 51 & $55 \quad 16$ & 71 & 35860 & 418 & 579 & 753 \\
\hline Passing threshold & -24 & -30 & $-18 \quad-6$ & -24 & & & & & & & & \\
\hline Statistical mutation & & & & & & & & & 16 & 22 & 37 & 47 \\
\hline 1997-98 & $791 \quad 176$ & 967 & $992 \quad 277$ & 1269 & 95 & 132 & 86 & 124 & $886 \quad 213$ & 1099 & 1078 & 1393 \\
\hline
\end{tabular}

1) The cleaning has been performed in 1984, the situation after the cleaning has been calculated with the data of $1981 / 82$. 
This certainly seems reasonable if the CTS and NCTS values of the category "disappeared" are compared to the $\mathrm{N}$ - and Z- treatment, however this assumption cannot be quantified. Apart from that, a tree classified as "disappeared" could also have been measured and considered an ingrower. All these kinds of insecurities influence the consistency of the ingrowth and increment figures. Therefore, it is desirable to analyse the diameter increment of those trees that were clearly found again.

The discrepancy between the passing thresholds in the PCQ-inventories (measured at only 12\% of the surface area) to the PSP-inventory over the $25 \mathrm{~cm}$ limit asks for a category "statistical mutation". Next to that, the trees that belong to the mutation category "other tree" add to the category "statistical mutation".

Table 12: Dynamics merchantable volume in $\mathrm{m}^{3} / \mathrm{ha} 1981$ - 1997

\begin{tabular}{|c|c|c|c|c|c|c|c|c|c|c|c|c|c|c|c|c|c|}
\hline \multirow{5}{*}{$\begin{array}{c}\text { Mapane } \\
1981-1997\end{array}$} & \multicolumn{5}{|c|}{ PCQ random sample $d<25 \mathrm{~cm}$} & \multicolumn{6}{|c|}{ PSP - inventory: $d>=25 \mathrm{~cm}$} & \multicolumn{6}{|c|}{ Total } \\
\hline & \multicolumn{5}{|c|}{ Cleaning } & \multicolumn{6}{|c|}{ Cleaning } & \multicolumn{6}{|c|}{ Cleaning } \\
\hline & \multicolumn{2}{|c|}{ none/light } & \multicolumn{3}{|c|}{ heavy } & \multicolumn{3}{|c|}{ none/light } & \multicolumn{3}{|c|}{ heavy } & \multicolumn{3}{|c|}{ none/light } & \multicolumn{3}{|c|}{ heavy } \\
\hline & \multicolumn{2}{|c|}{ Timberclass } & \multicolumn{3}{|c|}{ Timberclass } & \multicolumn{3}{|c|}{ Timberclass } & \multicolumn{3}{|c|}{ Timberclass } & \multicolumn{3}{|c|}{ Timberclass } & \multicolumn{3}{|c|}{ Timberclass } \\
\hline & NCTS CTS & Тот & NCTS & CTS & Тот & NCTS & CTS & Тот & NCTS & CTS & Тот & NCTS & CTS & Тот & NCTS & CTS & Tот \\
\hline 1981-82 & 24 & 30 & 13 & 4 & 17 & 163 & 61 & 224 & 171 & 77 & 248 & 188 & 66 & 254 & 184 & 81 & 265 \\
\hline Cleaning ${ }^{1)}$ & & & & & & -23 & 0 & -23 & -122 & 0 & -122 & -23 & 0 & -23 & -122 & 0 & -122 \\
\hline After cleaning ${ }^{1)}$ & 24 & 30 & 13 & 4 & 17 & 140 & 61 & 200 & 49 & 77 & 125 & 164 & 66 & 230 & 61 & 81 & 142 \\
\hline Logging & & & & & & -1 & -7 & -8 & 0 & -8 & -8 & -1 & -7 & -8 & 0 & -8 & -8 \\
\hline Mortality & -1 & -4 & -2 & 0 & -2 & -28 & -7 & -35 & -3 & -10 & -13 & -31 & -8 & -39 & -5 & -11 & -15 \\
\hline Disappeared & $-10 \quad-2$ & -12 & -5 & -2 & -7 & -27 & -13 & -40 & -9 & -29 & -39 & -37 & -16 & -52 & -14 & -31 & -45 \\
\hline Ingrowth & 3 & 3 & 11 & 3 & 14 & 36 & 9 & 45 & 50 & 14 & 64 & 3 & 0 & 3 & 11 & 3 & 14 \\
\hline Passing threshold & -19 & -23 & -12 & -5 & -17 & & & & & & & & & & & & \\
\hline Increment & 30 & 38 & 20 & 8 & 28 & 31 & 13 & 44 & 16 & 16 & 32 & 61 & 21 & 82 & 36 & 25 & 60 \\
\hline Statiatical mutation & & & & & & 8 & 1 & 9 & 2 & 0 & 2 & 26 & 7 & 32 & 40 & 9 & 49 \\
\hline 1997-98 & 25 & 33 & 26 & 8 & 34 & 159 & 57 & 216 & 104 & 59 & 163 & 184 & 65 & 249 & 130 & 67 & 197 \\
\hline
\end{tabular}

1) The cleaning has been performed in 1984, the situation after the cleaning has been calculated with the data of $1981 / 82$.

From Table 12 the effect of the treatment on the volume-growth can be derived, which is listed in Table 13.

Table 13: Effect of the treatment on the volume-growth $>25 \mathrm{~cm}$

\begin{tabular}{|l|r|r|}
\hline & NCTS & CTS \\
\hline Ingrowth - difference between treatment & 13.5 & 4.8 \\
Increment - difference between treatment & -15.2 & 3.2 \\
Growth - difference between treatment in $\mathrm{m}^{3} / \mathrm{ha} \mathrm{per} 16 \mathrm{yr}^{3} / \mathrm{ha}^{1} / \mathrm{yr}$ & -1.7 & 8.0 \\
Annual growth - difference between treatment in $\mathrm{m}^{3} \mathrm{ha}^{1} / \mathrm{yr}$ & -0.10 & 0.50 \\
Average annual growth - untreated $\mathrm{m}^{3} / .19$ & 1.40 \\
\hline Growth change due to treatment & $-2 \%$ & $36 \%$ \\
\hline
\end{tabular}

In Table 14, Table 15 and Figure 5, Figure 6 insight is provided to see where the stemnumbers and the basal area are disappearing; this is in the higher diameters. 


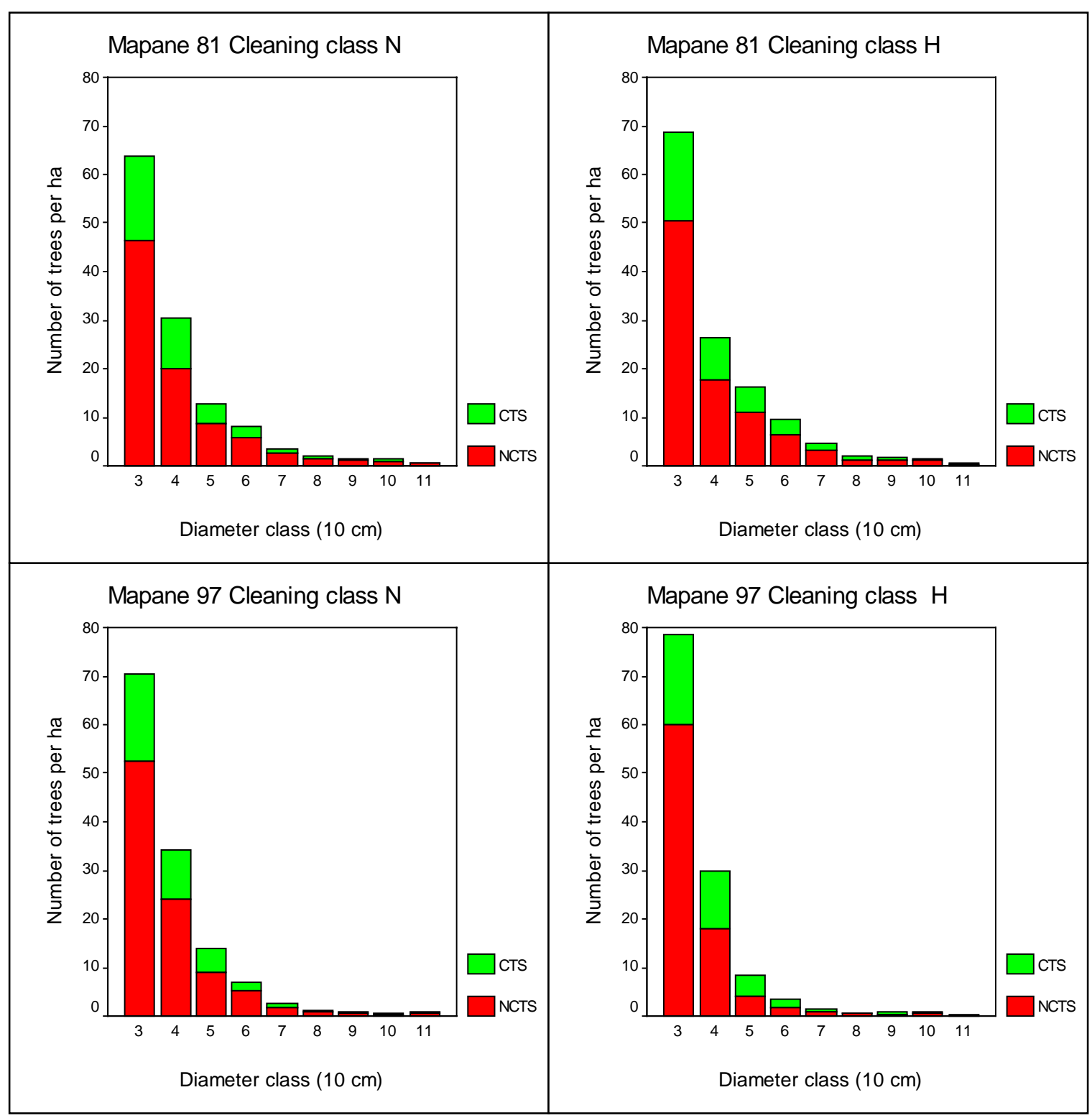

Figure 5: Changes in the diameter class division before and after the treatment

Table 14: Diameter-stemnumber-division (number per ha)

\begin{tabular}{|r|r|r|r|r|r|r|r|r|}
\hline & \multicolumn{4}{|c|}{ Cleaning N } & \multicolumn{5}{|c|}{ Cleaning H } \\
\cline { 2 - 9 } Diameter class & \multicolumn{2}{|c|}{$\mathbf{1 9 8 1}$} & \multicolumn{2}{|c|}{$\mathbf{1 9 9 7}$} & \multicolumn{2}{|c|}{$\mathbf{1 9 8 1}$} & \multicolumn{2}{|c|}{$\mathbf{1 9 9 7}$} \\
\cline { 2 - 9 } & NCTS & \multicolumn{1}{|c|}{ CTS } & NCTS & CTS & NCTS & \multicolumn{1}{c|}{ CTS } & NCTS & \multicolumn{1}{c|}{ CTS } \\
\hline $5-15 \mathrm{~cm}$ & 510 & 135 & 647 & 144 & 479 & 127 & 838 & 238 \\
$15-25 \mathrm{~cm}$ & 133 & 27 & 144 & 33 & 75 & 17 & 155 & 39 \\
$25-35 \mathrm{~cm}$ & 46 & 17 & 53 & 18 & 50 & 18 & 60 & 19 \\
$35-45 \mathrm{~cm}$ & 20 & 10 & 24 & 10 & 18 & 9 & 18 & 12 \\
$45-55 \mathrm{~cm}$ & 9 & 4 & 9 & 5 & 11 & 5 & 4 & 4 \\
$55-65 \mathrm{~cm}$ & 6 & 2 & 5 & 2 & 6 & 3 & 2 & 2 \\
$65-75 \mathrm{~cm}$ & 3 & 1 & 2 & 1 & 3 & 1 & 1 & 0 \\
$75-85 \mathrm{~cm}$ & 2 & 1 & 1 & 0 & 1 & 1 & 0 & 0 \\
$85-95 \mathrm{~cm}$ & 1 & 0 & 1 & 0 & 1 & 1 & 0 & 1 \\
$95-105 \mathrm{~cm}$ & 1 & 1 & 0 & 0 & 1 & 0 & 1 & 0 \\
$>105 \mathrm{~cm}$ & 1 & 0 & 1 & 0 & 0 & 0 & 0 & 0 \\
\hline total & 731 & 198 & 886 & 213 & 646 & 183 & 1078 & 314 \\
\hline
\end{tabular}




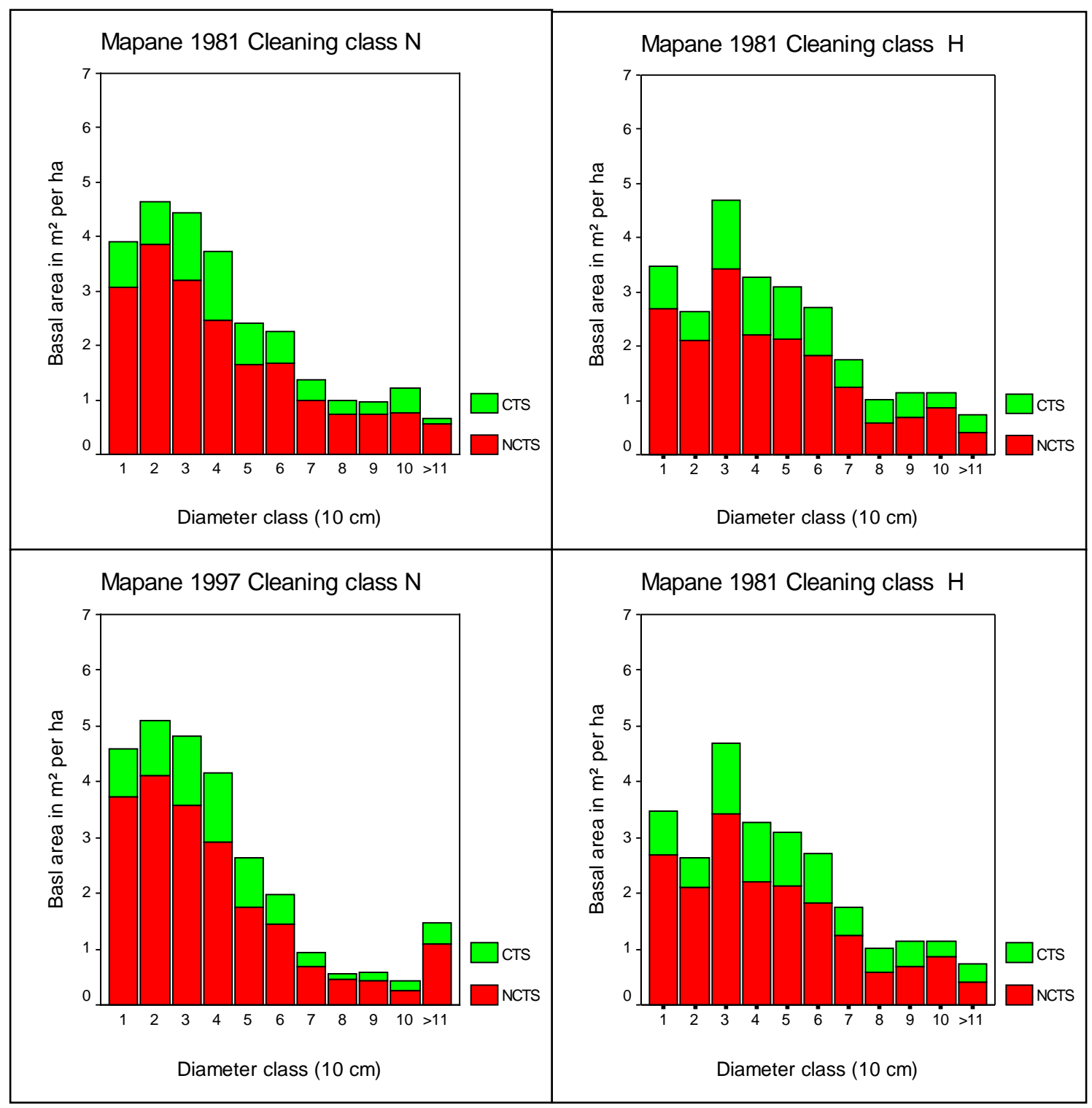

Figure 6: Changes in the basal area division per diameter class 1981 and 1997

Table 15: Diameter-Basal area-division ( $\mathrm{m}^{2}$ per ha)

\begin{tabular}{|r|r|r|r|r|r|r|r|r|}
\hline \multirow{2}{*}{$\begin{array}{c}\text { Diameter- } \\
\text { class }\end{array}$} & \multicolumn{4}{|c|}{ Cleaning N } & \multicolumn{4}{c|}{ Cleaning H } \\
\cline { 2 - 8 } & \multicolumn{2}{|c|}{ Gha 1981 } & \multicolumn{2}{|c|}{ Gha 1997 } & \multicolumn{2}{c|}{ Gha 1981 } & \multicolumn{2}{c|}{ Gha 1997 } \\
\hline $5-15 \mathrm{~cm}$ & 3.06 & 0.85 & 3.73 & 0.87 & 2.68 & 0.79 & 4.90 & 1.53 \\
$15-25 \mathrm{~cm}$ & 3.86 & 0.77 & 4.10 & 1.00 & 2.11 & 0.53 & 4.31 & 1.06 \\
$25-35 \mathrm{~cm}$ & 3.20 & 1.24 & 3.59 & 1.24 & 3.43 & 1.26 & 4.05 & 1.29 \\
$35-45 \mathrm{~cm}$ & 2.46 & 1.26 & 2.91 & 1.25 & 2.20 & 1.09 & 2.09 & 1.49 \\
$45-55 \mathrm{~cm}$ & 1.64 & 0.77 & 1.75 & 0.89 & 2.12 & 0.97 & 0.81 & 0.80 \\
$55-65 \mathrm{~cm}$ & 1.66 & 0.59 & 1.44 & 0.54 & 1.83 & 0.88 & 0.52 & 0.43 \\
$65-75 \mathrm{~cm}$ & 0.99 & 0.37 & 0.69 & 0.25 & 1.24 & 0.51 & 0.39 & 0.17 \\
$75-85 \mathrm{~cm}$ & 0.74 & 0.25 & 0.45 & 0.12 & 0.59 & 0.41 & 0.21 & 0.05 \\
$85-95 \mathrm{~cm}$ & 0.74 & 0.22 & 0.43 & 0.16 & 0.69 & 0.45 & 0.11 & 0.39 \\
$95-105 \mathrm{~cm}$ & 0.77 & 0.44 & 0.25 & 0.19 & 0.87 & 0.27 & 0.42 & 0.13 \\
$>105 \mathrm{~cm}$ & 0.57 & 0.09 & 1.09 & 0.38 & 0.42 & 0.32 & 0.00 & 0.20 \\
\hline total & 19.68 & 6.87 & 20.42 & 6.90 & 18.17 & 7.48 & 17.81 & 7.54 \\
\hline
\end{tabular}




\section{Diameter increment}

The last option is to look at the diameter increment of the stems that have remained and try to find whether there is a difference between the treatments. Usually, the diameter increment is determined by the $2^{\text {nd }}$ degree polynom, as function of the diameter per species. See below:

$$
\text { id }=a_{0}+a_{1} * d+a_{2} * d^{2}
$$

In addition, the age can play a role in this uneven-aged forest. In Mapane quite a lot of species appear, that is why species-groups have been made with comparable diameter increment (see Table 17 for the names, codes and numbers). Using an ANOVA-model, it was tested whether the cleaning-class had some effect, see Table 16 and Figure 7 for the results. The diameter increment function is taken into consideration by using covariates in the ANOVA-model. Only the "intercept" $\left(\mathrm{a}_{0}\right)$ was tested for the cleaning-class effect, not the $\mathrm{a}_{1}$ or $\mathrm{a}_{2}$ constants, because these describe the effect of the treatment the best.

If all species would have been used in the model instead of the species-groups an adjusted $\mathrm{R}^{2}$ of 0.37 can be reached. Using the seven species groups a respectable part of this is explained, namely 0.28 . Of course, a higher $\mathrm{R}^{2}$ can be reached with a species-specific $\mathrm{a}_{1}$ and $\mathrm{a}_{2}$, however this barely makes a difference (0.29).

Table 16: ANOVA of id with the effects cleaning-class, species group, and covariates $d(D B H)$ and $d^{2}\left(D B H^{2}\right)$.

\begin{tabular}{|l|rrrrr|}
\hline Source & \multicolumn{1}{l}{$\begin{array}{l}\text { Type III Sum } \\
\text { of Squares }\end{array}$} & df & Mean Square & \multicolumn{1}{c|}{ F } & \multicolumn{1}{c|}{ Sig. } \\
\hline Corrected Model & 65.246 & 9 & 7.250 & 133.420 & .000 \\
Intercept & 34.079 & 1 & 34.079 & 627.190 & .000 \\
Tree species group & 47.493 & 6 & 7.916 & 145.677 & .000 \\
Cleaning-class & 1.065 & 1 & 1.065 & 19.592 & .000 \\
DBH & 4.142 & 1 & 4.142 & 76.229 & .000 \\
DBH & 3.030 & 1 & 3.030 & 55.764 & .000 \\
Error & 164.694 & 3031 & 0.054 & & \\
Total & 411.974 & 3041 & & & \\
Corrected Total & 229.940 & 3040 & & & \\
\hline
\end{tabular}

R Squared $=.284$ (Adjusted R Squared $=.282$ )

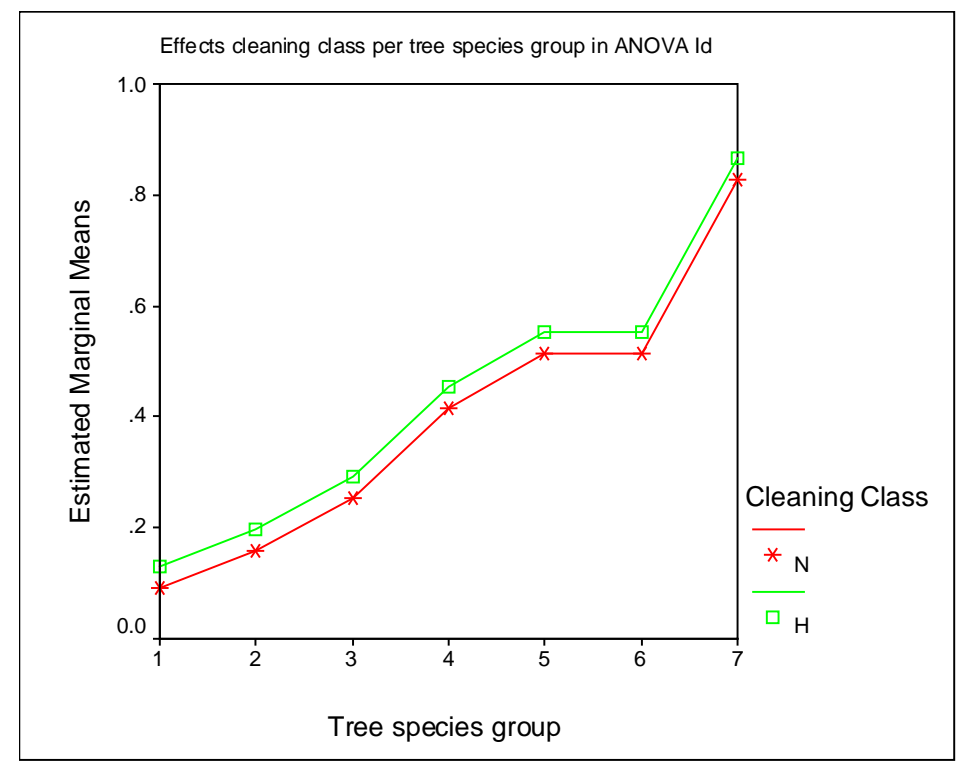

Figure 7: Diameter increment in $\mathrm{cm} / \mathrm{yr}$ for each cleaning class ( $\mathrm{N}$ and $\mathrm{H}$ ) and tree species group (x-axis).

The values show that all effects are significant. In addition, the interactions between the Hendrison-effect and North-South have been taken into consideration, as well as the interactions 
with the others. Nothing out of that group appeared to be significant. From ANOVA it cannot clearly be derived whether the cleaning-class effect is either positive or negative. The answer appears to be positive and Figure 7 shows this. The positive effect of the cleaning class is on average $0.038 \mathrm{~cm} / \mathrm{yr}$ higher. It seems not much; however, it concerns over $16 \%$ more diameter increment. According to Schneider's law, this comes down to 33\% more volume increment. There are no significant differences between CTS and NCTS.

Table 17: Tree species (groups) in ANOVA-model id

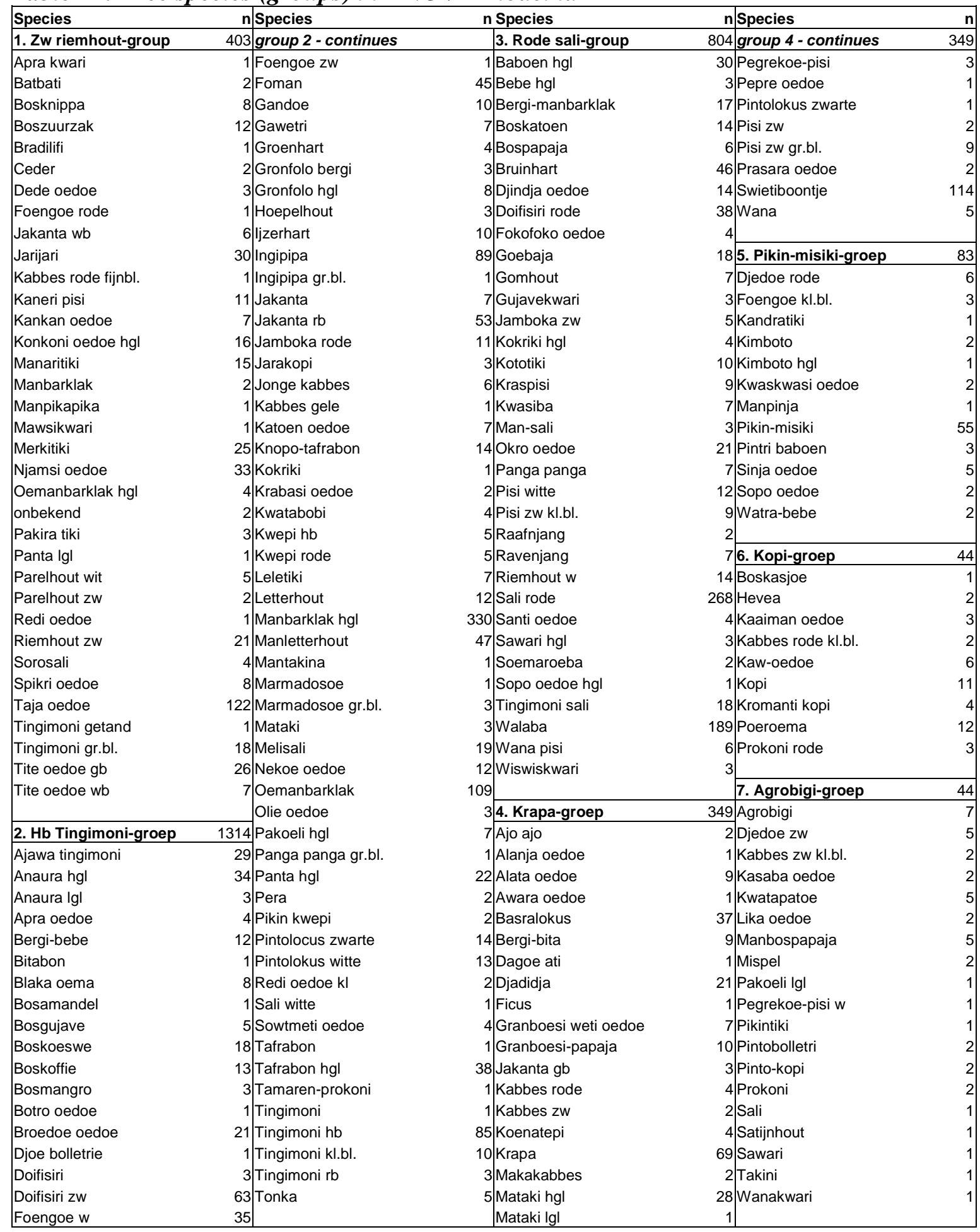




\section{Damage and mortality}

The mortality (see Table 18) appears to be significant depending on the cleaning-class even though the $\mathrm{R}^{2}$ adj is low. After an N-cleaning the basal area decreased with $2.74 \mathrm{~m}^{2} / \mathrm{ha}$ in 16 years, after a Z-cleaning this is $1.15 \mathrm{~m}^{2} / \mathrm{ha}$. In comparison to the original basal area, it concerns a mortality of $1.09 \%$ and $0.39 \%$ per year respectively. The tree mortality furthermore seems to be independent of the tree diameter.

Table 18: ANOVA of $G_{m o r}$ with the effect cleaning-class (CC)

\begin{tabular}{|l|r|r|r|r|r|}
\hline Source & $\begin{array}{c}\text { Type III Sum } \\
\text { of Squares }\end{array}$ & Df & Mean Square & \multicolumn{1}{c|}{ F } & Sig. \\
\hline Corrected Model & $14.603(\mathrm{a})$ & 1 & 14.603 & 7.530 & 0.012 \\
Intercept & 87.025 & 1 & 87.025 & 44.872 & 0.000 \\
CC & 14.603 & 1 & 14.603 & 7.530 & 0.012 \\
Error & 40.727 & 21 & 1.939 & & \\
Total & 145.654 & 23 & & & \\
Corrected Total & 55.330 & 22 & & & \\
\hline
\end{tabular}

a R Squared $=.264$ (Adjusted R Squared $=.229$ )

Damage to the trees seems to be mainly diameter dependent and next to this, less in the case of an N-cleaning

\section{Table 19: Damage per cleaning-class}

\begin{tabular}{|l|r|r|r|}
\hline \multirow{2}{*}{ Damage class } & \multicolumn{2}{|c|}{ Cleaning-class } & \multirow{2}{*}{ Total } \\
\cline { 2 - 3 } & N & H & 3917 \\
Non & 1895 & 2022 & 64 \\
Hollow or rotten & 37 & 27 & 68 \\
Broken off & 44 & 24 & 263 \\
Other damage & 125 & 138 & 26 \\
Girdled & 5 & 21 & 4338 \\
\hline Total & 2106 & 2232 & \\
\hline
\end{tabular}




\section{Discussion}

The Celos Silvicultural System treatment in Mapane can be classified in the classes "not or lightly cleaned" $(\mathrm{N})$ and "heavily cleaned" $(\mathrm{H})$.

The ingrowth above the measurment-limit of $5 \mathrm{~cm}$ (PCQ-inventories) and $25 \mathrm{~cm}$ (PSP-inventories) in terms of basal area per ha is considerably (4x) higher in the class "Z" compared to "N". The Celos Harvesting System with controlled harvest increases this effect even more (7 times higher than the N-treatment without harvest).

The increment in basal area per ha does not seem to differ significantly per treatment, this can be explained by the other mutations in the experimental plots than the originally planned measures, namely logging. The individual diameter increment appeared to be significantly higher in the "H"-class by almost half a millimetre a year. The increase is not very species specific, so the CTS as well as the NCTS groups gain equal profit out of the treatment. Given that the species composition is regulated by the treatments, there is a shift towards more CTSspecies. There also were no differences between NCTS and CTS-species for the ingrowth.

Since there were no interventions in the class below $25 \mathrm{~cm}$, the composition will again shift to the situation before the treatment on the long term. Continuance cleaning will eventually give a forest with a higher share of CTS-species. This research, however, does not provide a quantitative support, except a strong suggestion.

The inventories are of average quality. After 16 years, it appeared to be very difficult to find the marked trees again. Harvest took also place in the same period, which made it even more difficult. Crucial for this kind of permanent experimental plots (PSP) is the existence of a tree position map and permanent marks on the corner of the subplots. This appeared not to be the case. Another crucial aspect is to determine the classes of change, damage, etc in advance. Peculiar enough all these kind of issues were registered in detail for the inventory protocol. It is unclear whether it was actually used, in any case the information was absent in the original database. 


\section{Literature}

Bus, D. en B. Laumans, 1997a. Rapportage werkzaamheden Mapane. Betreffende de activiteiten van de meetploeg in de periode maart - september 1997. Centrum voor Landbouwkundig Onderzoek in Suriname, Paramaribo.

Bus, D. en B. Laumans, 1997b. Rapportage verblijk Suriname. Verslag van werkzaamheden uitgevoerd in het kader van het Na-doctoraal Onderzoek Programma (NOP) - november 1997. Centrum voor Landbouwkundig Onderzoek in Suriname, Paramaribo.

Graaf, N.R. de, 1986. A silvicultural system for natural regeneration of tropical rain forest in Suriname. Ph.D. Thesis, Wageningen Agricultural University, The Netherlands

Hendrison, J., 1990. Damage-controlled logging in Managed Tropical Rain Forest in Suriname. Ph.D. Thesis, Wageningen Agricultural University

Jonkers, W.B.J., 1987. Vegetation structure, logging damage and silviculture in tropical rain forest in Suriname. Ph.D. Thesis Wageningen Agricultural University.

Steege, H. ter, B. Laumans, D. Laumans-Bus, G. Zondervan, F. Bongers, 2003. Long-term effect of timber harvesting in Mapane - North Suriname. In: H. ter Steege (ed.), 2003 Long-term changes in tropical tree diversity: Studies from the Guiana Shield, Africa, Borneo and Melanesia. Tropenbos Series 22, Tropenbos International, Wageningen, the Netherlands, 215 pp. ISBN 90-5113-065; ISSN 1383-6811; 79-94.

Vletter, J. de, 1980. Voorstel praktijkproef natuurlijke bosverjonging te Mapane, Suriname Forest Service, Paramaribo. 
Appendix I. Frequency division timber species and diameter increment (PCQ + PSP)

\begin{tabular}{|c|c|c|c|c|c|c|c|c|c|c|}
\hline \multirow[b]{3}{*}{ Timber species* } & \multirow{2}{*}{\multicolumn{2}{|c|}{ CELOS-timber code }} & \multirow{3}{*}{$\begin{array}{r}\text { total } \\
\mathrm{nr} \\
\text { obser }\end{array}$} & \multicolumn{3}{|c|}{ Number observations ( $\mathrm{n}$ ) of id } & \multicolumn{4}{|c|}{ Average diameter increment (id) in cm/yr } \\
\hline & & & & \multirow[b]{2}{*}{ all } & \multirow{2}{*}{$\begin{array}{l}\text { With } 0+\mathrm{L} \\
\text { treatment }\end{array}$} & \multirow{2}{*}{$\begin{array}{l}\text { With } \mathrm{M}+\mathrm{Z} \\
\text { treatment }\end{array}$} & \multirow{2}{*}{$\begin{array}{r}\text { id } \\
\text { (all) }\end{array}$} & \multirow{2}{*}{$\begin{array}{r}\text { id } \\
(0+L)\end{array}$} & \multirow{2}{*}{$\begin{array}{r}\text { id } \\
(M+Z)\end{array}$} & \multirow{2}{*}{$\begin{array}{r}\text { Difference of } \\
\text { treatments }\end{array}$} \\
\hline & Code & Class & & & & & & & & \\
\hline$(1)$ & (2) & (3) & $(4)$ & (5) & (6) & $(7)$ & $(8)$ & $(9)$ & $(10)$ & $(11)$ \\
\hline Abrasa & & & 2 & & & & & & & \\
\hline Agrobigi & 11350301 & CTS & 16 & 7 & 4 & 3 & 1,06 & 1,30 & & \\
\hline Ajawa tingimoni & 11120401 & CTS & 63 & 29 & 13 & 16 & 0,23 & 0,24 & 0,23 & $-0,02$ \\
\hline Ajo ajo & 04251001 & NCTS & 5 & 2 & & 2 & & & & \\
\hline Alanja oedoe & 00353601 & NCTS & 1 & 1 & & 1 & & & & \\
\hline Alata oedoe & 04480201 & NCTS & 33 & 9 & 5 & 4 & 0,38 & 0,45 & 0,28 & $-0,17$ \\
\hline Anaura hgl & 02540101 & NCTS & 79 & 35 & 23 & 12 & 0,21 & 0,18 & 0,27 & 0,09 \\
\hline Anaura lgl & 05540308 & NCTS & 6 & 3 & & 3 & & & & \\
\hline Anaura zwamp & 05540308 & NCTS & 3 & & & & & & & \\
\hline Apra kwari & 00680301 & NCTS & 1 & 1 & & 1 & & & & \\
\hline Apra oedoe & 04580503 & NCTS & 6 & 4 & 2 & 2 & 0,14 & & & \\
\hline Awara oedoe & 05150201 & NCTS & 9 & 1 & 1 & & & & & \\
\hline Baboen hgl & 11430201 & CTS & 88 & 30 & 10 & 20 & 0,32 & 0,32 & 0,32 & 0,00 \\
\hline Baboen lgl & 11430201 & CTS & 1 & & & & & & & \\
\hline Barklak hgl & 11430201 & CTS & 1 & & & & & & & \\
\hline Basralokus & 11351601 & CTS & 98 & 40 & 10 & 30 & 0,49 & 0,46 & 0,50 & 0,04 \\
\hline Batbati & 04040101 & NCTS & 6 & 2 & 2 & & & & & \\
\hline Bebe & 05353402 & NCTS & 2 & & & & & & & \\
\hline Bebe hgl & 05353402 & NCTS & 4 & 3 & 3 & & & & & \\
\hline Bebe lgl & 05353402 & NCTS & 1 & & & & & & & \\
\hline Bergi-bebe & 02353603 & NCTS & 30 & 12 & 3 & 9 & 0,17 & & 0,21 & \\
\hline Bergi-bita & 04040501 & NCTS & 12 & 10 & 4 & 6 & 0,39 & 0,31 & 0,45 & 0,14 \\
\hline Bergi-manbarklak & 02340404 & NCTS & 34 & 18 & & 18 & 0,22 & & 0,22 & \\
\hline Bitabon & 00260201 & NCTS & 1 & 1 & 1 & & & & & \\
\hline Blaka oema & 05220101 & NCTS & 36 & 9 & 4 & 5 & 0,19 & 0,17 & 0,21 & 0,04 \\
\hline Bofroe oedoe & 05220101 & NCTS & 2 & & & & & & & \\
\hline Boromang & 05220101 & NCTS & 7 & & & & & & & \\
\hline Bosamandel & 04190303 & NCTS & 4 & 1 & & 1 & & & & \\
\hline Bosgujave & 00450702 & NCTS & 8 & 5 & 4 & 1 & 0,13 & 0,16 & & \\
\hline Boskasjoe & 04020103 & NCTS & 2 & 1 & 1 & & & & & \\
\hline Boskatoen & 04100102 & NCTS & 23 & 14 & 10 & 4 & 0,33 & 0,27 & 0,47 & 0,20 \\
\hline Boskers & 04450401 & NCTS & 3 & & & & & & & \\
\hline Bosknippa & 04570501 & NCTS & 16 & 8 & 1 & 7 & 0,00 & & $-0,01$ & \\
\hline Boskoeswe & 00090101 & NCTS & 44 & 18 & 14 & 4 & 0,11 & 0,08 & 0,24 & 0,16 \\
\hline Boskoffie & 00550401 & NCTS & 22 & 14 & 8 & 6 & 0,17 & 0,11 & 0,24 & 0,13 \\
\hline Bosmangro & 04270701 & NCTS & 6 & 3 & & 3 & & & & \\
\hline Bospapaja & 04420301 & NCTS & 111 & 6 & 5 & 1 & 0,27 & 0,28 & & \\
\hline Boszuurzak & 04030101 & NCTS & 20 & 12 & 8 & 4 & 0,08 & 0,04 & 0,15 & 0,11 \\
\hline Boszuurzak zwamp & 04030101 & NCTS & 1 & & & & & & & \\
\hline Botro oedoe & 04030101 & NCTS & 4 & 1 & & 1 & & & & \\
\hline Bradilifi & 05500101 & NCTS & 1 & 1 & & 1 & & & & \\
\hline Broedoe oedoe & 04430103 & NCTS & 53 & 21 & 12 & 9 & 0,24 & 0,22 & 0,28 & 0,07 \\
\hline Bruinhart & 11354201 & CTS & 77 & 47 & 14 & 33 & 0,29 & 0,22 & 0,31 & 0,10 \\
\hline Ceder & 11400201 & CTS & 3 & 2 & 2 & & & & & \\
\hline Dagoe ati & 04251101 & NCTS & 1 & 1 & & 1 & & & & \\
\hline Dede oedoe & 05550201 & NCTS & 3 & 3 & 2 & 1 & & & & \\
\hline Djadidja & 02353503 & NCTS & 83 & 21 & 14 & 7 & 0,41 & 0,49 & 0,26 & $-0,22$ \\
\hline Djedoe rode & 02353501 & NCTS & 35 & 6 & 4 & 2 & 0,80 & 1,04 & & \\
\hline Djedoe w & 00353505 & NCTS & 2 & & & & & & & \\
\hline Djedoe zw & 02353504 & NCTS & 9 & 5 & & 5 & 1,15 & & 1,15 & \\
\hline Djindja oedoe & 03190101 & NCTS & 21 & 14 & 11 & 3 & 0,35 & 0,39 & & \\
\hline Djoe bolletrie & 03190101 & NCTS & 3 & 1 & & 1 & & & & \\
\hline Doifisiri & 04400301 & NCTS & 6 & 4 & 3 & 1 & 0,25 & & & \\
\hline Doifisiri rode & 04400301 & NCTS & 80 & 39 & 35 & 4 & 0,35 & 0,35 & 0,36 & 0,01 \\
\hline
\end{tabular}




\begin{tabular}{|c|c|c|c|c|c|c|c|c|c|c|}
\hline \multirow[b]{3}{*}{ Timber species* } & \multirow{2}{*}{\multicolumn{2}{|c|}{ CELOS-timber code }} & \multirow{3}{*}{$\begin{array}{r}\text { total } \\
\mathrm{nr} \\
\text { obser }\end{array}$} & \multicolumn{3}{|c|}{ Number observations ( $\mathrm{n}$ ) of id } & \multicolumn{4}{|c|}{ Average diameter increment (id) in $\mathrm{cm} / \mathrm{yr}$} \\
\hline & & & & \multirow[b]{2}{*}{ all } & \multirow{2}{*}{$\begin{array}{c}\text { With } 0+\mathrm{L} \\
\text { treatment }\end{array}$} & \multirow{2}{*}{$\begin{array}{l}\text { With } M+Z \\
\text { treatment }\end{array}$} & \multirow{2}{*}{$\begin{array}{r}\text { id } \\
\text { (all) }\end{array}$} & \multirow{2}{*}{$\begin{array}{r}\text { id } \\
(0+L)\end{array}$} & \multirow{2}{*}{$\begin{array}{r}\text { id } \\
(M+Z)\end{array}$} & \multirow{2}{*}{$\begin{array}{r}\text { Difference of } \\
\text { treatments }\end{array}$} \\
\hline & Code & Class & & & & & & & & \\
\hline$(1)$ & $(2)$ & (3) & $(4)$ & (5) & $(6)$ & $(7)$ & $(8)$ & (9) & $(10)$ & $(11)$ \\
\hline Doifisiri wb & 04400301 & NCTS & 2 & & & & & & & \\
\hline Doifisiri zw & 04400302 & NCTS & 128 & 63 & 27 & 36 & 0,14 & 0,13 & 0,15 & 0,02 \\
\hline Ficus & 00420401 & NCTS & 2 & 1 & 1 & & & & & \\
\hline Foengoe kl.bl. & 03540313 & NCTS & 5 & 4 & 1 & 3 & 0,41 & & & \\
\hline Foengoe rode & 03540401 & NCTS & 5 & 1 & & 1 & & & & \\
\hline Foengoe w & 03250701 & NCTS & 85 & 36 & 20 & 16 & 0,25 & 0,25 & 0,26 & 0,01 \\
\hline Foengoe zw & 03540309 & NCTS & 6 & 1 & & 1 & & & & \\
\hline Foengoe zw kl.bl. & 03540309 & NCTS & 1 & & & & & & & \\
\hline Fokofoko oedoe & 04640101 & NCTS & 8 & 4 & 3 & 1 & 0,26 & & & \\
\hline Foman & 03250401 & NCTS & 101 & 46 & 20 & 26 & 0,20 & 0,17 & 0,22 & 0,04 \\
\hline Gandoe & 04353607 & NCTS & 22 & 10 & 5 & 5 & 0,09 & 0,08 & 0,10 & 0,03 \\
\hline Gandoe zw & 04353607 & NCTS & 1 & & & & & & & \\
\hline Gawetri & 04570201 & NCTS & 16 & 7 & 4 & 3 & 0,14 & 0,08 & & \\
\hline Gawetri witte & 04570201 & NCTS & 1 & & & & & & & \\
\hline Goebaja & 11080101 & CTS & 65 & 18 & 7 & 11 & 0,32 & 0,22 & 0,38 & 0,16 \\
\hline Gomhout & 04251601 & NCTS & 29 & 7 & 6 & 1 & 0,36 & 0,30 & & \\
\hline Granboesi-papaja & 04420801 & NCTS & 138 & 10 & 9 & 1 & 0,59 & 0,64 & & \\
\hline $\begin{array}{l}\text { Granboesi weti oe- } \\
\text { doe }\end{array}$ & 04020402 & NCTS & 32 & 7 & 3 & 4 & 0,45 & & 0,21 & \\
\hline Groenhart & 11080204 & CTS & 8 & 4 & 3 & 1 & 0,12 & & & \\
\hline Gronfolo & 11680204 & CTS & 2 & & & & & & & \\
\hline Gronfolo bergi & 11680204 & CTS & 16 & 4 & & 4 & 0,14 & & 0,14 & \\
\hline Gronfolo hgl & 11680201 & CTS & 21 & 8 & 4 & 4 & 0,27 & 0,18 & 0,37 & 0,20 \\
\hline Gujavekwari & 04680203 & NCTS & 10 & 3 & 3 & & & & & \\
\hline Hevea & 04250801 & NCTS & 2 & 2 & 1 & 1 & & & & \\
\hline Hoepelhout & 04351201 & NCTS & 5 & 3 & 2 & 1 & & & & \\
\hline IJzerhart & 02353905 & NCTS & 30 & 12 & 2 & 10 & 0,14 & & 0,16 & \\
\hline Ingipipa & 03340201 & NCTS & 208 & 89 & 72 & 17 & 0,27 & 0,23 & 0,43 & 0,20 \\
\hline Ingipipa gr.bl. & 03340201 & NCTS & 1 & 1 & 1 & & & & & \\
\hline Jakanta & 00310101 & NCTS & 37 & 8 & 1 & 7 & 0,28 & & 0,31 & \\
\hline Jakanta gb & 05360101 & NCTS & 7 & 3 & & 3 & & & & \\
\hline Jakanta gr.bl. & 00310101 & NCTS & 1 & & & & & & & \\
\hline Jakanta hgl & 00310101 & NCTS & 1 & & & & & & & \\
\hline Jakanta rb & 00310101 & NCTS & 121 & 54 & 32 & 22 & 0,17 & 0,11 & 0,26 & 0,15 \\
\hline Jakanta wb & 03310301 & NCTS & 25 & 6 & 2 & 4 & 0,09 & & 0,04 & \\
\hline Jamboka & 03580504 & NCTS & 1 & & & & & & & \\
\hline Jamboka rode & 03580504 & NCTS & 33 & 12 & 8 & 4 & 0,11 & 0,11 & 0,09 & $-0,02$ \\
\hline Jamboka zw & 04580501 & NCTS & 22 & 5 & 2 & 3 & 0,24 & & & \\
\hline Jarakopi & 00630101 & NCTS & 16 & 3 & 1 & 2 & & & & \\
\hline Jarijari & 00030401 & NCTS & 82 & 30 & 19 & 11 & 0,10 & 0,10 & 0,10 & 0,00 \\
\hline Jonge kabbes & 04354101 & NCTS & 11 & 6 & 4 & 2 & 0,19 & 0,17 & & \\
\hline Kaaiman oedoe & 01040201 & NCTS & 13 & 3 & 2 & 1 & & & & \\
\hline Kabbes gele & 04354001 & NCTS & 1 & 1 & 1 & & & & & \\
\hline Kabbes rode & 11351001 & CTS & 5 & 4 & 3 & 1 & 0,27 & & & \\
\hline Kabbes rode fijnbl. & 01350607 & NCTS & 1 & 1 & 1 & & & & & \\
\hline Kabbes rode kl.bl. & 01350607 & NCTS & 2 & 2 & 1 & 1 & & & & \\
\hline Kabbes zw & 11351801 & CTS & 3 & 2 & 1 & 1 & & & & \\
\hline Kabbes zw kl.bl. & 11351801 & CTS & 4 & 2 & 1 & 1 & & & & \\
\hline Kandra oedoe & 11351801 & CTS & 1 & & & & & & & \\
\hline Kandratiki & 00550801 & NCTS & 1 & 1 & 1 & & & & & \\
\hline Kaneri pisi & 11330302 & CTS & 34 & 11 & 4 & 7 & 0,07 & 0,09 & 0,06 & $-0,03$ \\
\hline Kankan oedoe & 04640101 & NCTS & 14 & 7 & 6 & 1 & 0,14 & 0,12 & & \\
\hline Kankantri & 05100301 & NCTS & 1 & & & & & & & \\
\hline Kasaba oedoe & 13060101 & CTS & 9 & 2 & 1 & 1 & & & & \\
\hline Katoen oedoe & 04640201 & NCTS & 15 & 7 & 5 & 2 & 0,22 & 0,21 & & \\
\hline Kaw-oedoe & 05420101 & NCTS & 7 & 6 & 6 & & 0,57 & 0,57 & & \\
\hline Kimboto & 04580506 & NCTS & 2 & 2 & 2 & & & & & \\
\hline Kimboto berg & 04580506 & NCTS & 1 & & & & & & & \\
\hline
\end{tabular}




\begin{tabular}{|c|c|c|c|c|c|c|c|c|c|c|}
\hline \multirow[b]{3}{*}{ Timber species* } & \multirow{2}{*}{\multicolumn{2}{|c|}{ CELOS-timber code }} & \multirow{3}{*}{$\begin{array}{r}\text { total } \\
\mathrm{nr} \\
\text { obser }\end{array}$} & \multicolumn{3}{|c|}{ Number observations $(n)$ of id } & \multicolumn{4}{|c|}{ Average diameter increment (id) in cm/yr } \\
\hline & & & & \multirow[b]{2}{*}{ all } & \multirow{2}{*}{$\begin{array}{l}\text { With } 0+\mathrm{L} \\
\text { treatment }\end{array}$} & \multirow{2}{*}{$\begin{array}{l}\text { With } \mathrm{M}+\mathrm{Z} \\
\text { treatment }\end{array}$} & \multirow{2}{*}{$\begin{array}{r}\text { id } \\
\text { (all) }\end{array}$} & \multirow{2}{*}{$\begin{array}{r}\text { id } \\
(0+L)\end{array}$} & \multirow{2}{*}{$\begin{array}{r}\text { id } \\
(M+Z)\end{array}$} & \multirow{2}{*}{$\begin{array}{r}\text { Difference of } \\
\text { treatments }\end{array}$} \\
\hline & Code & Class & & & & & & & & \\
\hline$(1)$ & $(2)$ & (3) & $(4)$ & (5) & (6) & $(7)$ & (8) & $(9)$ & $(10)$ & (11) \\
\hline Kimboto hgl & 04580506 & NCTS & 1 & 1 & 1 & & & & & \\
\hline Knopo-tafrabon & 00110102 & NCTS & 38 & 14 & 8 & 6 & 0,10 & 0,11 & 0,09 & $-0,02$ \\
\hline Koenatepi & 11353201 & CTS & 6 & 4 & 3 & 1 & 0,19 & & & \\
\hline Kokriki & 04353004 & NCTS & 1 & 1 & 1 & & & & & \\
\hline Kokriki hgl & 04353004 & NCTS & 6 & 4 & 2 & 2 & 0,22 & & & \\
\hline Konkoni oedoe & 05340502 & NCTS & 3 & & & & & & & \\
\hline Konkoni oedoe hgl & 05340502 & NCTS & 29 & 17 & 8 & 9 & 0,08 & 0,07 & 0,09 & 0,03 \\
\hline Kopi & 11170101 & CTS & 36 & 12 & 3 & 9 & 0,45 & & 0,55 & \\
\hline kototiki & 11170101 & CTS & 3 & & & & & & & \\
\hline Kototiki & 00251801 & NCTS & 34 & 11 & 10 & 1 & 0,24 & 0,25 & & \\
\hline Krabasi oedoe & 04190301 & NCTS & 4 & 2 & 2 & & & & & \\
\hline Krapa & 11400102 & CTS & 151 & 70 & 39 & 31 & 0,45 & 0,42 & 0,49 & 0,07 \\
\hline Kraspisi & 00330508 & NCTS & 27 & 9 & 4 & 5 & 0,29 & 0,45 & 0,17 & $-0,28$ \\
\hline Kromanti kopi & 01040201 & NCTS & 18 & 4 & 3 & 1 & 0,37 & & & \\
\hline Kwari rode & 00680303 & NCTS & 1 & & & & & & & \\
\hline Kwasiba & 04580513 & NCTS & 20 & 7 & 5 & 2 & 0,29 & 0,26 & & \\
\hline Kwaskwasi oedoe & 04650101 & NCTS & 10 & 2 & 2 & & & & & \\
\hline Kwatabobi & 00580201 & NCTS & 9 & 4 & 3 & 1 & 0,16 & & & \\
\hline Kwatakama & 04350302 & NCTS & 3 & & & & & & & \\
\hline Kwatapatoe & 11340601 & CTS & 10 & 5 & 2 & 3 & 0,78 & & & \\
\hline Kwepi & 04540301 & NCTS & 3 & & & & & & & \\
\hline Kwepi hb & 00540704 & NCTS & 18 & 5 & 1 & 4 & 0,15 & & 0,16 & \\
\hline Kwepi rode & 00540601 & NCTS & 13 & 5 & 3 & 2 & 0,22 & & & \\
\hline Laksiri hgl & 00540601 & NCTS & 1 & & & & & & & \\
\hline Laurierkers & 00581001 & NCTS & 1 & & & & & & & \\
\hline Leletiki & 00670201 & NCTS & 11 & 7 & 2 & 5 & 0,11 & & 0,09 & \\
\hline Letterhout & 11420701 & CTS & 22 & 13 & 4 & 9 & 0,26 & 0,10 & 0,34 & 0,25 \\
\hline Lika oedoe & 05370101 & NCTS & 5 & 2 & & 2 & & & & \\
\hline Makakabbes & 04352401 & NCTS & 3 & 2 & 1 & 1 & & & & \\
\hline Man-bebe berg & 04352401 & NCTS & 1 & & & & & & & \\
\hline Man-sali & 00250501 & NCTS & 11 & 3 & 2 & 1 & & & & \\
\hline Manaritiki & 00670202 & NCTS & 22 & 15 & 2 & 13 & 0,09 & & 0,08 & \\
\hline Manbarklak & 02340408 & NCTS & 17 & 2 & 1 & 1 & & & & \\
\hline Manbarklak hgl & 02340405 & NCTS & 608 & 360 & 211 & 149 & 0,13 & 0,12 & 0,14 & 0,01 \\
\hline Manbebe & 00250201 & NCTS & 3 & 1 & & 1 & & & & \\
\hline Manbospapaja & 04420302 & NCTS & 137 & 5 & 4 & 1 & 0,68 & 0,52 & & \\
\hline Mangandoe berg & 04420302 & NCTS & 1 & & & & & & & \\
\hline Manletterhout & 01420601 & NCTS & 123 & 48 & 24 & 24 & 0,22 & 0,15 & 0,28 & 0,13 \\
\hline Manpikapika & 09999999 & NCTS & 1 & 1 & & 1 & & & & \\
\hline Manpinja & 00270801 & NCTS & 3 & 1 & & 1 & & & & \\
\hline Mantakina & 00270801 & NCTS & 1 & 1 & 1 & & & & & \\
\hline Мapa & 03040401 & NCTS & 1 & & & & & & & \\
\hline Marmadosoe & 05550101 & NCTS & 7 & 1 & & 1 & & & & \\
\hline Marmadosoe gr.bl. & 05550101 & NCTS & 4 & 3 & 2 & 1 & & & & \\
\hline Marmadosoe kl. & 05550101 & NCTS & 1 & & & & & & & \\
\hline Mataki & 11270601 & CTS & 5 & 3 & 3 & & & & & \\
\hline Mataki hgl & 11270601 & CTS & 68 & 29 & 14 & 15 & 0,35 & 0,31 & 0,38 & 0,07 \\
\hline Mataki lgl & 11270601 & CTS & 2 & 1 & & 1 & & & & \\
\hline Mawsikwari & 00680101 & NCTS & 8 & 1 & 1 & & & & & \\
\hline Melisali & 00400403 & NCTS & 48 & 19 & 10 & 9 & 0,12 & 0,12 & 0,11 & $-0,01$ \\
\hline Merki oedoe & 00400403 & NCTS & 1 & & & & & & & \\
\hline Merkitiki & 00041001 & NCTS & 69 & 25 & 13 & 12 & 0,08 & 0,06 & 0,10 & 0,04 \\
\hline Miera oedoe & 02500202 & NCTS & 1 & & & & & & & \\
\hline Mispel & 00390101 & NCTS & 32 & 2 & 1 & 1 & & & & \\
\hline Mispel gr.bl. & 00390101 & NCTS & 1 & & & & & & & \\
\hline Moetene & 00390101 & NCTS & 1 & & & & & & & \\
\hline Nekoe oedoe & 04350901 & NCTS & 25 & 13 & 9 & 4 & 0,25 & 0,31 & 0,12 & $-0,19$ \\
\hline Njamsi oedoe & 05460101 & NCTS & 66 & 33 & 26 & 7 & 0,05 & 0,04 & 0,10 & 0,05 \\
\hline
\end{tabular}




\begin{tabular}{|c|c|c|c|c|c|c|c|c|c|c|}
\hline \multirow[b]{3}{*}{ Timber species* } & \multirow{2}{*}{\multicolumn{2}{|c|}{ CELOS-timber code }} & \multirow{3}{*}{$\begin{array}{r}\text { total } \\
\mathrm{nr} \\
\text { obser } \\
\end{array}$} & \multicolumn{3}{|c|}{ Number observations $(n)$ of id } & \multicolumn{4}{|c|}{ Average diameter increment (id) in cm/yr } \\
\hline & & & & \multirow[b]{2}{*}{ all } & \multirow{2}{*}{$\begin{array}{l}\text { With } 0+\mathrm{L} \\
\text { treatment }\end{array}$} & \multirow{2}{*}{$\begin{array}{l}\text { With } M+Z \\
\text { treatment }\end{array}$} & \multirow{2}{*}{$\begin{array}{r}\text { id } \\
\text { (all) }\end{array}$} & \multirow{2}{*}{$\begin{array}{r}\text { id } \\
(0+L)\end{array}$} & \multirow{2}{*}{$\begin{array}{r}i d \\
(M+Z) \\
\end{array}$} & \multirow{2}{*}{$\begin{array}{r}\text { Difference of } \\
\text { treatments }\end{array}$} \\
\hline & Code & Class & & & & & & & & \\
\hline$(1)$ & $(2)$ & (3) & $(4)$ & $(5)$ & (6) & $(7)$ & (8) & (9) & (10) & $(11)$ \\
\hline Njamsi oedoe kl & 05460101 & NCTS & 1 & & & & & & & \\
\hline Oema oedoe & 05260102 & NCTS & 2 & & & & & & & \\
\hline Oemanbarklak & 02340403 & NCTS & 179 & 116 & 65 & 51 & 0,16 & 0,14 & 0,19 & 0,05 \\
\hline Oemanbarklak hgl & 02340403 & NCTS & 11 & 5 & 4 & 1 & 0,05 & 0,05 & & \\
\hline Oeproe olie & 02340403 & NCTS & 1 & & & & & & & \\
\hline Okro oedoe & 11600101 & CTS & 60 & 21 & 12 & 9 & 0,57 & 0,66 & 0,47 & $-0,19$ \\
\hline Olie oedoe & 00421001 & NCTS & 27 & 3 & 2 & 1 & & & & \\
\hline Onbekend(unknow) & & & 14 & 2 & 1 & 1 & & & & \\
\hline Pakira tiki & 00200101 & NCTS & 11 & 3 & 3 & & & & & \\
\hline Pakoeli hgl & 01270503 & NCTS & 14 & 7 & 3 & 4 & 0,10 & & 0,11 & \\
\hline Pakoeli lgl & 11270401 & NCTS & 1 & 1 & 1 & & & & & \\
\hline Panga panga & 00550901 & NCTS & 27 & 7 & 4 & 3 & 0,30 & 0,48 & & \\
\hline Panga panga gr.bl. & 00550901 & NCTS & 1 & 1 & 1 & & & & & \\
\hline Panga panga hgl & 00550901 & NCTS & 1 & & & & & & & \\
\hline Panga panga kl.bl. & 00550901 & NCTS & 1 & & & & & & & \\
\hline Panta hgl & 00250501 & NCTS & 53 & 23 & 14 & 9 & 0,15 & 0,15 & 0,14 & $-0,01$ \\
\hline Panta lgl & 00250501 & NCTS & 2 & 1 & 1 & & & & & \\
\hline Panta wb & 00250501 & NCTS & 2 & & & & & & & \\
\hline Parelhout & 06040203 & NCTS & 2 & & & & & & & \\
\hline Parelhout wit & 06040203 & NCTS & 11 & 5 & 2 & 3 & 0,17 & & & \\
\hline Parelhout zw & 00040202 & NCTS & 7 & 2 & & 2 & & & & \\
\hline Pegrekoe-pisi & 11030301 & CTS & 12 & 3 & & 3 & & & & \\
\hline Pegrekoe-pisi rood & 01030302 & NCTS & 4 & 1 & & 1 & & & & \\
\hline Pegrekoe-pisi w & 11030301 & CTS & 7 & 1 & 1 & & & & & \\
\hline Pepre oedoe & 04251201 & NCTS & 1 & 1 & & 1 & & & & \\
\hline Pera & 03040401 & NCTS & 7 & 2 & 1 & 1 & & & & \\
\hline Pikin-misiki & 03350501 & NCTS & 155 & 56 & 45 & 11 & 0,54 & 0,54 & 0,55 & 0,02 \\
\hline Pikin kwepi & 00540313 & NCTS & 5 & 2 & & 2 & & & & \\
\hline Pikintiki & 04251101 & NCTS & 1 & 1 & 1 & & & & & \\
\hline Pinja oedoe & 00270802 & NCTS & 5 & & & & & & & \\
\hline Pinto-kopi & 04260301 & NCTS & 7 & 2 & 1 & 1 & & & & \\
\hline Pinto-kopi hg & 04260301 & NCTS & 2 & & & & & & & \\
\hline Pintobolletri & 00580514 & NCTS & 3 & 2 & & 2 & & & & \\
\hline Pintolocus zwarte & 00570502 & NCTS & 30 & 15 & 8 & 7 & 0,14 & 0,11 & 0,17 & 0,06 \\
\hline Pintolokus witte & 00355101 & NCTS & 22 & 13 & 8 & 5 & 0,21 & 0,23 & 0,17 & $-0,05$ \\
\hline Pintolokus zwarte & 00355101 & NCTS & 13 & 1 & 1 & & & & & \\
\hline Pintri baboen & 01430202 & NCTS & 8 & 3 & 1 & 2 & & & & \\
\hline Pisi spp. & 01430202 & NCTS & 1 & & & & & & & \\
\hline Pisi witte & 11330506 & CTS & 42 & 12 & 7 & 5 & 0,38 & 0,42 & 0,33 & $-0,08$ \\
\hline Pisi zw & 00330403 & NCTS & 2 & 2 & 1 & 1 & & & & \\
\hline Pisi zw gr.bl. & 11330401 & CTS & 17 & 9 & 8 & 1 & 0,37 & 0,38 & & \\
\hline Pisi zw kl.bl. & 11330503 & CTS & 22 & 9 & 5 & 4 & 0,31 & 0,26 & 0,39 & 0,13 \\
\hline Poeroema & 04420304 & NCTS & 101 & 12 & 7 & 5 & 0,68 & 0,73 & 0,60 & $-0,13$ \\
\hline Prasara oedoe & 05460102 & NCTS & 4 & 2 & 2 & & & & & \\
\hline Prokoni & 00350201 & NCTS & 5 & 2 & 2 & & & & & \\
\hline Prokoni rode & 00350201 & NCTS & 25 & 3 & 3 & & & & & \\
\hline Raafnjang & 05230101 & NCTS & 3 & 2 & & 2 & & & & \\
\hline Ravenjang & 00230101 & NCTS & 40 & 8 & 4 & 4 & 0,36 & 0,47 & 0,24 & $-0,23$ \\
\hline Redi oedoe & 05260101 & NCTS & 6 & 1 & & 1 & & & & \\
\hline Redi oedoe kl & 05260101 & NCTS & 3 & 2 & 1 & 1 & & & & \\
\hline Riemhout & 02560101 & NCTS & 1 & & & & & & & \\
\hline Riemhout w & 11580401 & CTS & 37 & 15 & 10 & 5 & 0,28 & 0,25 & 0,35 & 0,11 \\
\hline Riemhout zw & 11580402 & CTS & 65 & 21 & 18 & 3 & 0,13 & 0,13 & & \\
\hline Rode lokus & 11352301 & CTS & 1 & & & & & & & \\
\hline Sali & 11120301 & CTS & 2 & 1 & & 1 & & & & \\
\hline Sali hb & 11120301 & CTS & 1 & & & & & & & \\
\hline Sali rode & 11120301 & CTS & 516 & 276 & 203 & 73 & 0,25 & 0,24 & 0,27 & 0,04 \\
\hline Sali witte & 11120207 & CTS & 1 & 1 & 1 & & & & & \\
\hline
\end{tabular}




\begin{tabular}{|c|c|c|c|c|c|c|c|c|c|c|}
\hline \multirow[b]{3}{*}{ Timber species* } & \multirow{2}{*}{\multicolumn{2}{|c|}{ CELOS-timber code }} & \multirow{3}{*}{$\begin{array}{r}\text { total } \\
\mathrm{nr} \\
\text { obser }\end{array}$} & \multicolumn{3}{|c|}{ Number observations $(\mathrm{n})$ of id } & \multicolumn{4}{|c|}{ Average diameter increment (id) in $\mathrm{cm} / \mathrm{yr}$} \\
\hline & & & & \multirow[b]{2}{*}{ all } & \multirow{2}{*}{$\begin{array}{l}\text { With } 0+\mathrm{L} \\
\text { treatment }\end{array}$} & \multirow{2}{*}{$\begin{array}{l}\text { With } M+Z \\
\text { treatment }\end{array}$} & \multirow{2}{*}{$\begin{array}{r}\text { id } \\
\text { (all) }\end{array}$} & \multirow{2}{*}{$\begin{array}{r}\text { id } \\
(0+L)\end{array}$} & \multirow{2}{*}{$\begin{array}{r}\text { id } \\
(M+Z)\end{array}$} & \multirow{2}{*}{$\begin{array}{l}\text { Difference of } \\
\text { treatments }\end{array}$} \\
\hline & Code & Class & & & & & & & & \\
\hline$(1)$ & $(2)$ & (3) & $(4)$ & (5) & (6) & $(7)$ & $(8)$ & $(9)$ & $(10)$ & $(11)$ \\
\hline Santi oedoe & 04540310 & NCTS & 13 & 5 & 1 & 4 & 0,29 & & 0,29 & \\
\hline Satijnhout & 11420201 & CTS & 1 & 1 & & 1 & & & & \\
\hline Sawari & 05160103 & NCTS & 2 & 1 & & 1 & & & & \\
\hline Sawari hgl & 05160104 & NCTS & 16 & 5 & 3 & 2 & 0,36 & & & \\
\hline Sinja oedoe & 00550301 & NCTS & 16 & 5 & 3 & 2 & 0,48 & & & \\
\hline Soemaroeba & 11590401 & CTS & 17 & 2 & & 2 & & & & \\
\hline Sokosoko mapa & 11590401 & CTS & 3 & & & & & & & \\
\hline Sopo oedoe & 00160101 & NCTS & 8 & 2 & 1 & 1 & & & & \\
\hline Sopo oedoe hgl & 00160101 & NCTS & 2 & 1 & 1 & & & & & \\
\hline Sorosali & 05400401 & NCTS & 7 & 4 & 3 & 1 & 0,12 & & & \\
\hline Sowtmeti oedoe & 04170201 & NCTS & 6 & 4 & 3 & 1 & 0,29 & & & \\
\hline Spikri oedoe & 04390201 & NCTS & 14 & 8 & 6 & 2 & 0,08 & 0,09 & & \\
\hline Swa oedoe & 04390201 & NCTS & 1 & & & & & & & \\
\hline Swietiboontje & 04350202 & NCTS & 739 & 116 & 75 & 41 & 0,49 & 0,45 & 0,55 & 0,10 \\
\hline Tabakabron & 04250601 & NCTS & 8 & & & & & & & \\
\hline Tafrabon & 00110107 & NCTS & 2 & 1 & 1 & & & & & \\
\hline Tafrabon hgl & 00110107 & NCTS & 98 & 38 & 17 & 21 & 0,17 & 0,19 & 0,16 & $-0,03$ \\
\hline Taja oedoe & 00670102 & NCTS & 238 & 122 & 66 & 56 & 0,06 & 0,05 & 0,07 & 0,02 \\
\hline Takini & 00670102 & NCTS & 2 & 1 & & 1 & & & & \\
\hline Tamaren-prokoni & 03350101 & NCTS & 6 & 1 & 1 & & & & & \\
\hline Tamarinde hgl & 03350101 & NCTS & 1 & & & & & & & \\
\hline Tingimoni & 02120202 & NCTS & 1 & 1 & & 1 & & & & \\
\hline Tingimoni getand & 02120101 & NCTS & 8 & 1 & 1 & & & & & \\
\hline Tingimoni gr.bl. & 11120206 & CTS & 64 & 20 & 12 & 8 & 0,10 & 0,11 & 0,09 & $-0,03$ \\
\hline Tingimoni hb & 11120207 & CTS & 158 & 86 & 55 & 31 & 0,24 & 0,17 & 0,36 & 0,19 \\
\hline Tingimoni kl.bl. & 02120204 & NCTS & 38 & 11 & 1 & 10 & 0,21 & & 0,19 & \\
\hline Tingimoni rb & 02120208 & NCTS & 17 & 3 & 2 & 1 & & & & \\
\hline Tingimoni sali & 11120401 & CTS & 43 & 20 & & 20 & 0,23 & & 0,23 & \\
\hline Tite oedoe & 11120401 & CTS & 1 & & & & & & & \\
\hline Tite oedoe gb & 04340406 & NCTS & 41 & 27 & 22 & 5 & 0,13 & 0,11 & 0,19 & 0,08 \\
\hline Tite oedoe wb & 04340407 & NCTS & 17 & 8 & 5 & 3 & 0,17 & 0,05 & & \\
\hline Tonka & 11351901 & CTS & 5 & 5 & 2 & 3 & 0,13 & & & \\
\hline Walaba & 02352101 & NCTS & 397 & 204 & 125 & 79 & 0,27 & 0,24 & 0,31 & 0,06 \\
\hline Wana & 11330509 & CTS & 10 & 5 & 2 & 3 & 0,56 & & & \\
\hline Wana pisi & 11330502 & CTS & 11 & 6 & 2 & 4 & 0,38 & & 0,30 & \\
\hline Wanakwari & 11680305 & CTS & 3 & 1 & & 1 & & & & \\
\hline Watra-bebe & 02353401 & NCTS & 5 & 2 & 1 & 1 & & & & \\
\hline Weti oedoe & 02353401 & NCTS & 3 & & & & & & & \\
\hline Wiswiskwari & 11680302 & CTS & 7 & 3 & & 3 & & & & \\
\hline
\end{tabular}

Notice to Appendix I:

Column 4: number of observations per species in 1981, 1997, or both; uncorrected for PCQ subsampling.

Column 5: number of paired observations in 1981 and 1997 of which diameter increment could be derived.

Column 6: as column 5, concerning plots with no or light cleaning (“0+L”-ttreatment).

Column 7: as column 5, concerning plots with (middle) heavy cleaning ("M+Z”-treatment).

Column 8-10: average diameter increment in $\mathrm{cm} / \mathrm{yr}$ based on $\mathrm{n}$ observations of respectively column 5-7, presented when $n \geq 4$.

Column 11: difference between column 10 - column 9. NB: the difference for the CTS-species should be positive.

* See Appendix III for the scientific names of the above timber species. 


\section{Appendix II. Stem number mutations per tree species and treatment in number per ha for the period 1981 - 1997}

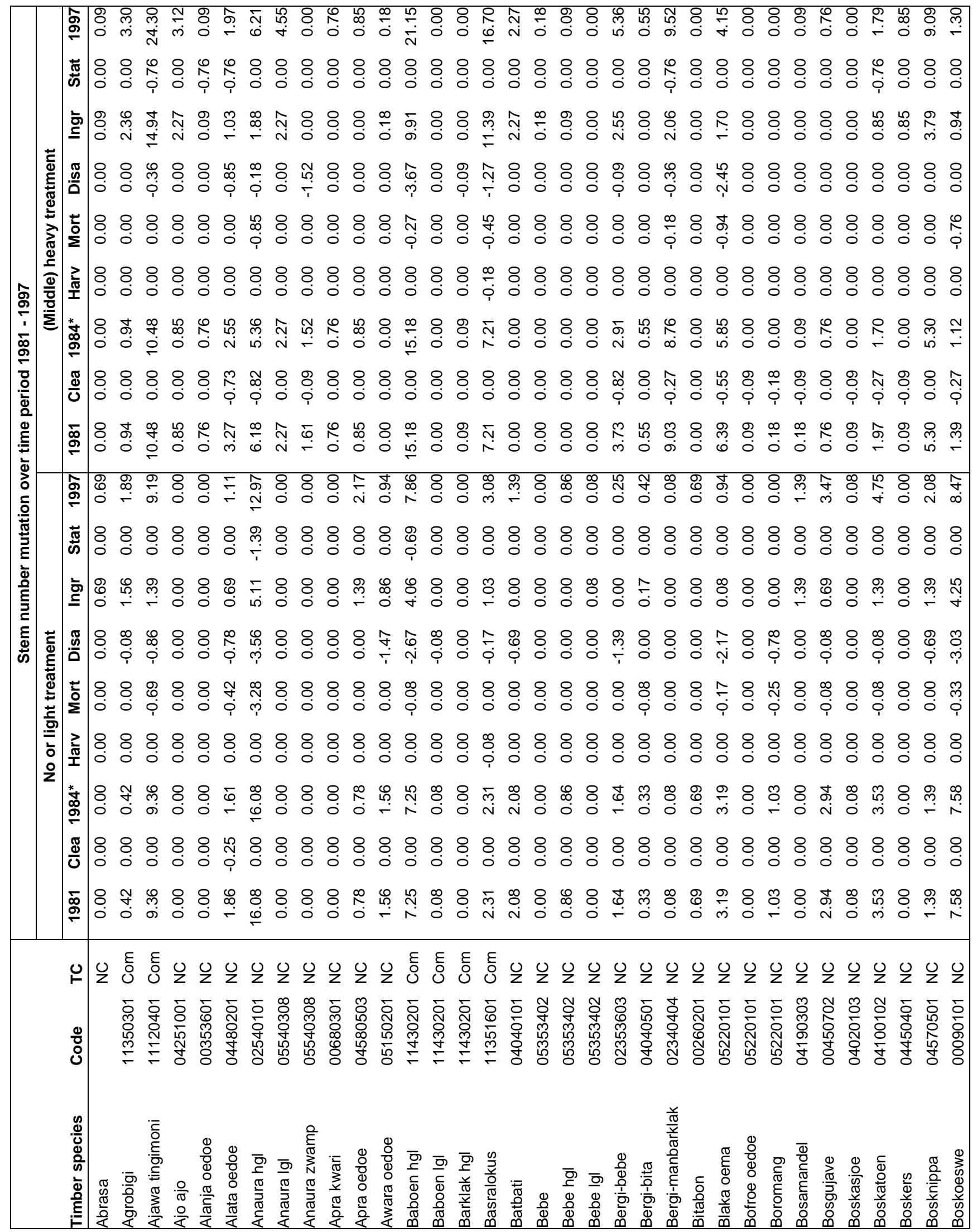




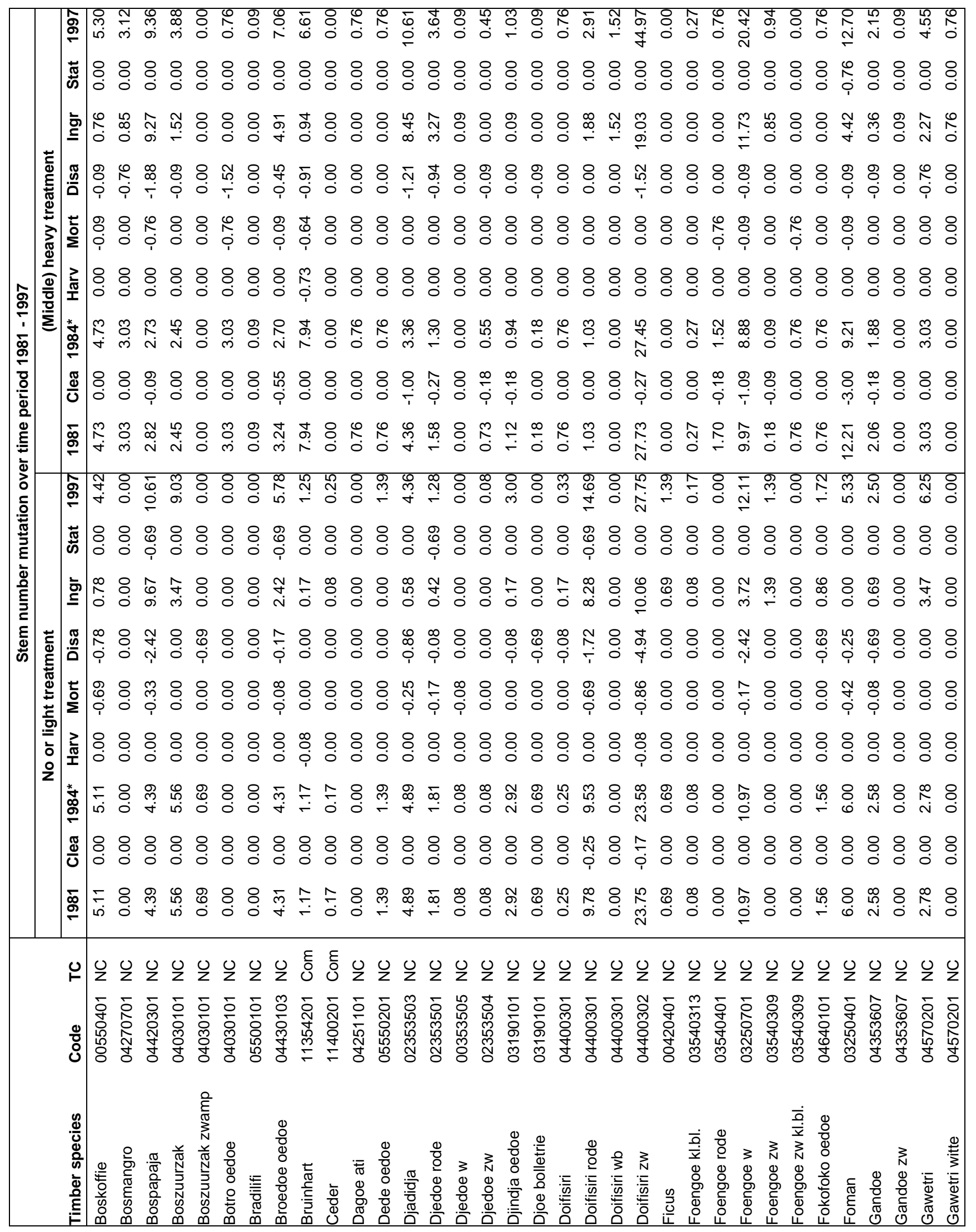




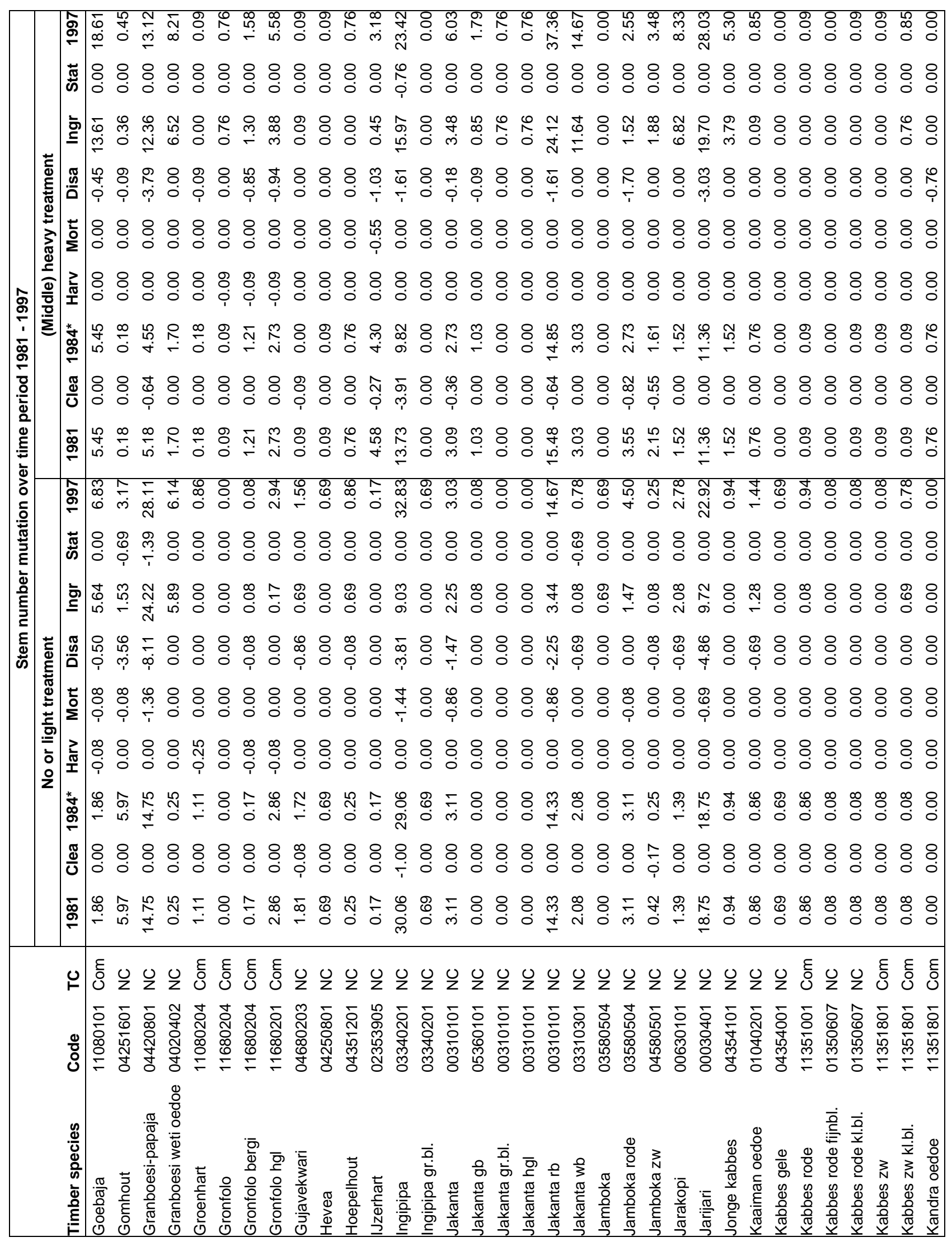




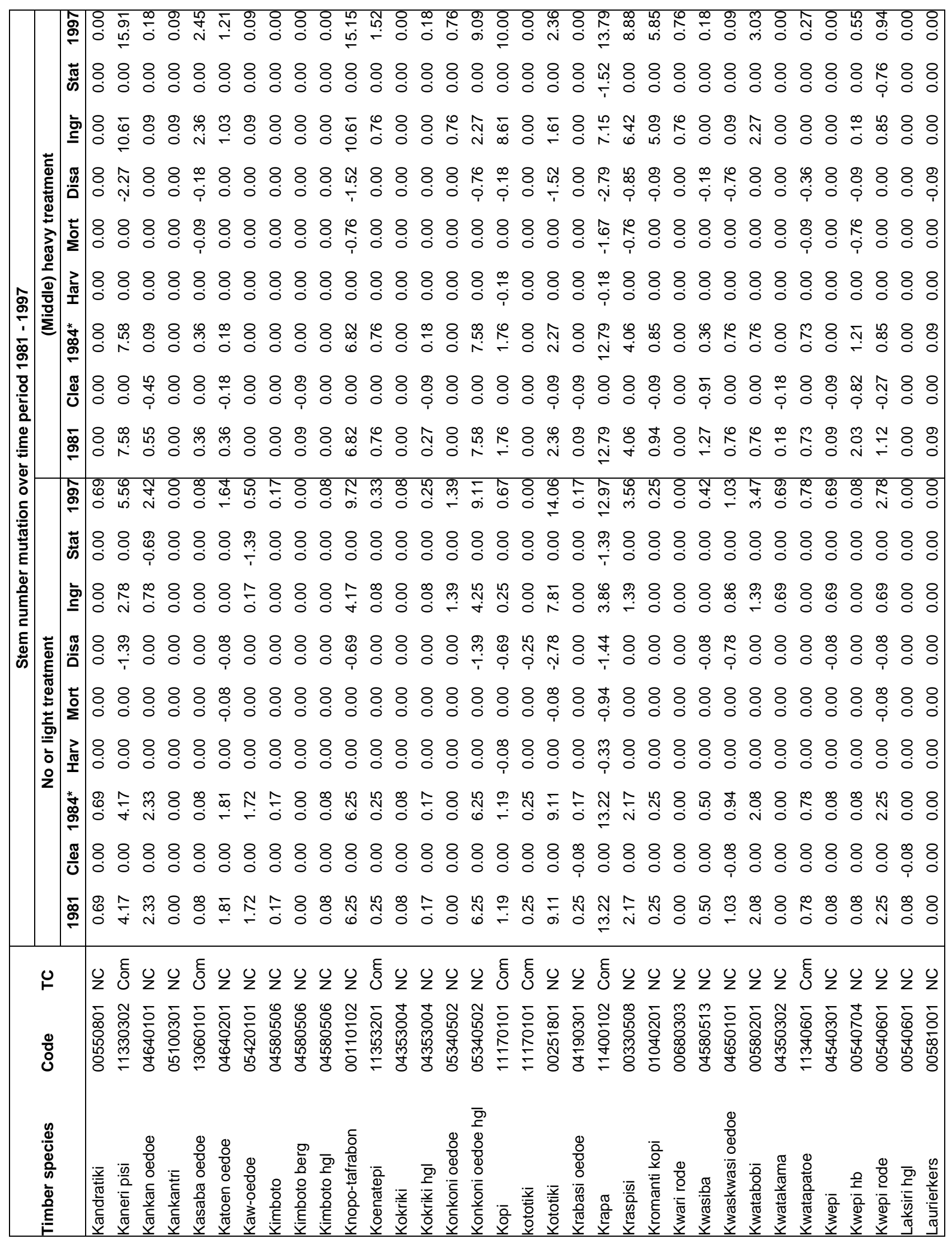




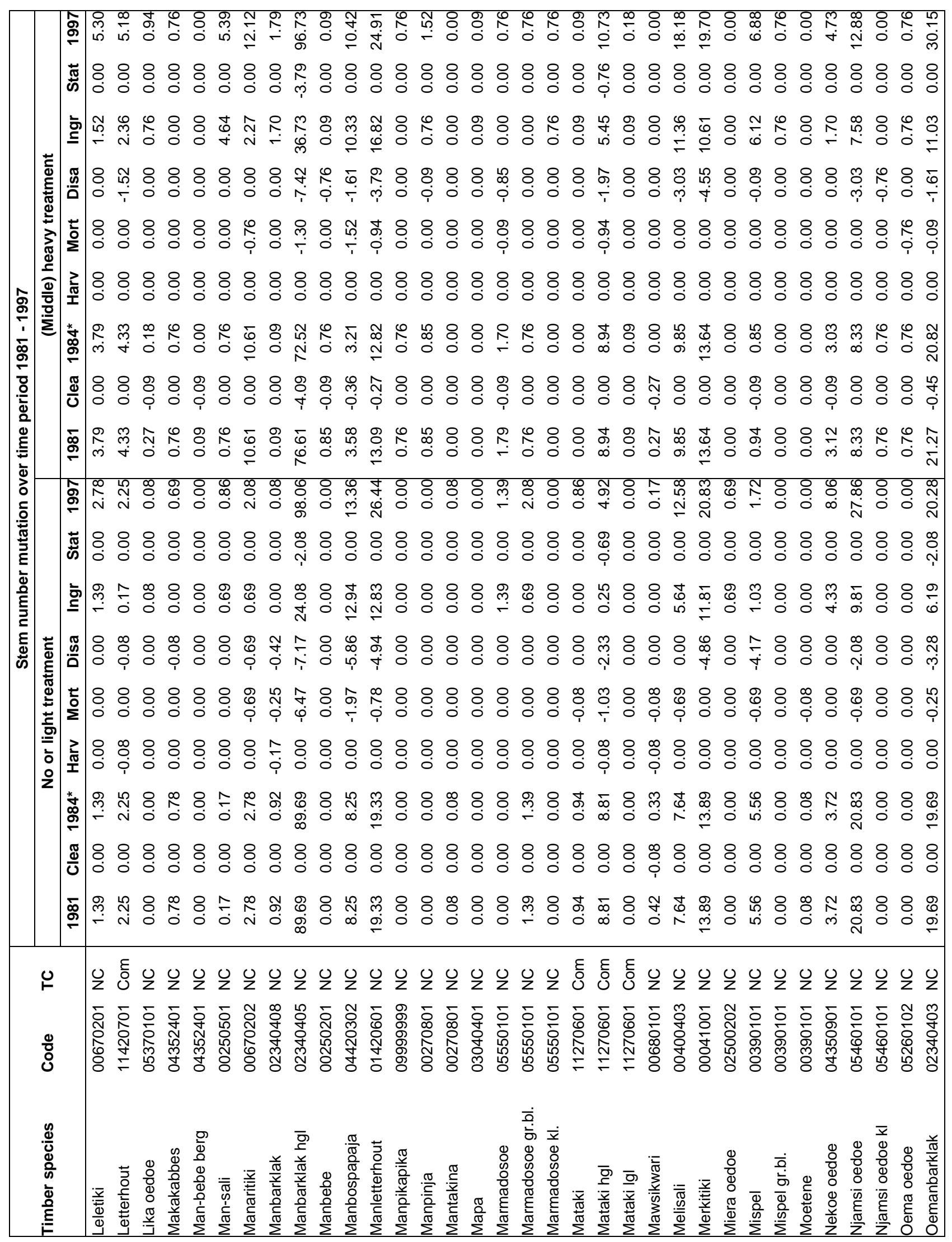




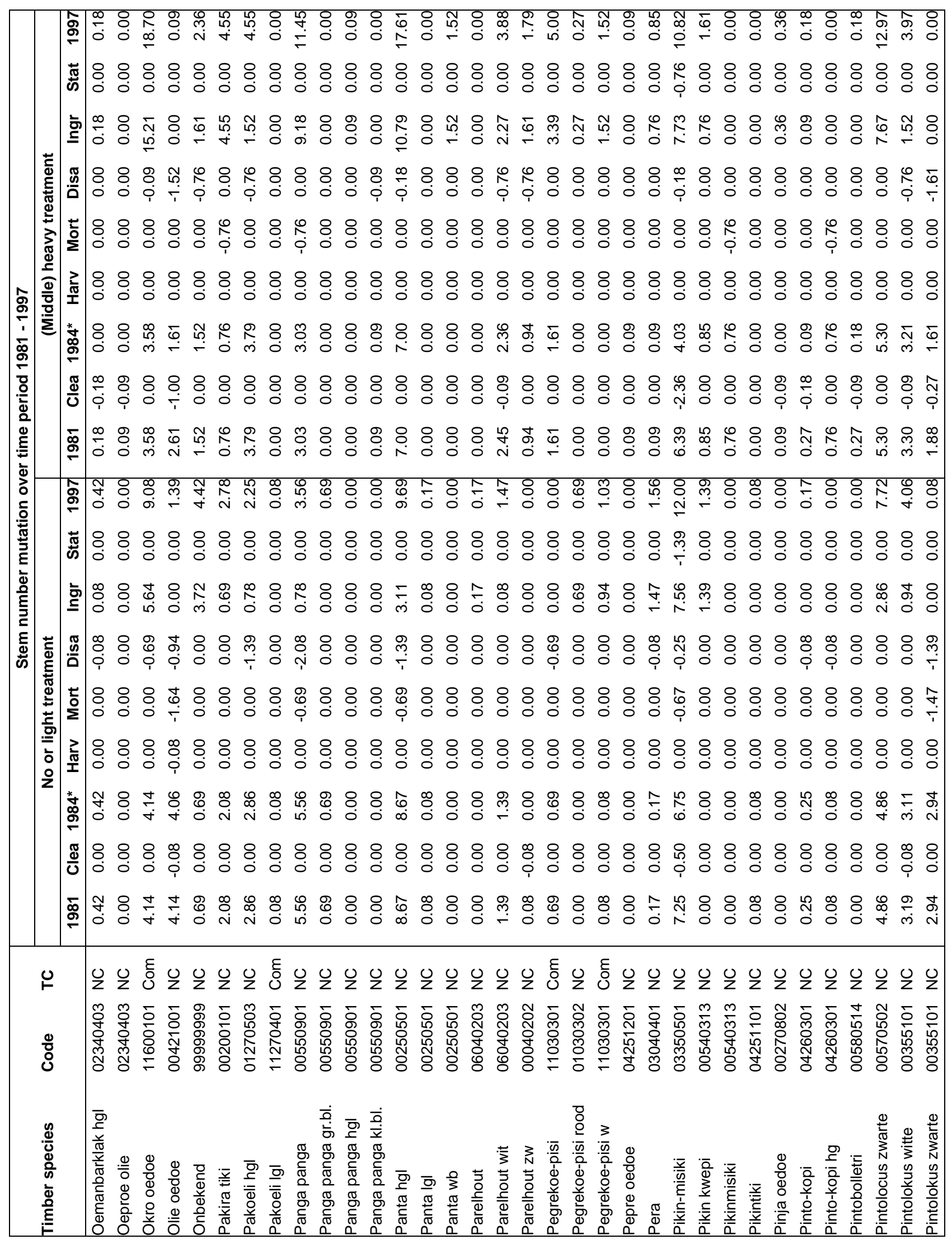




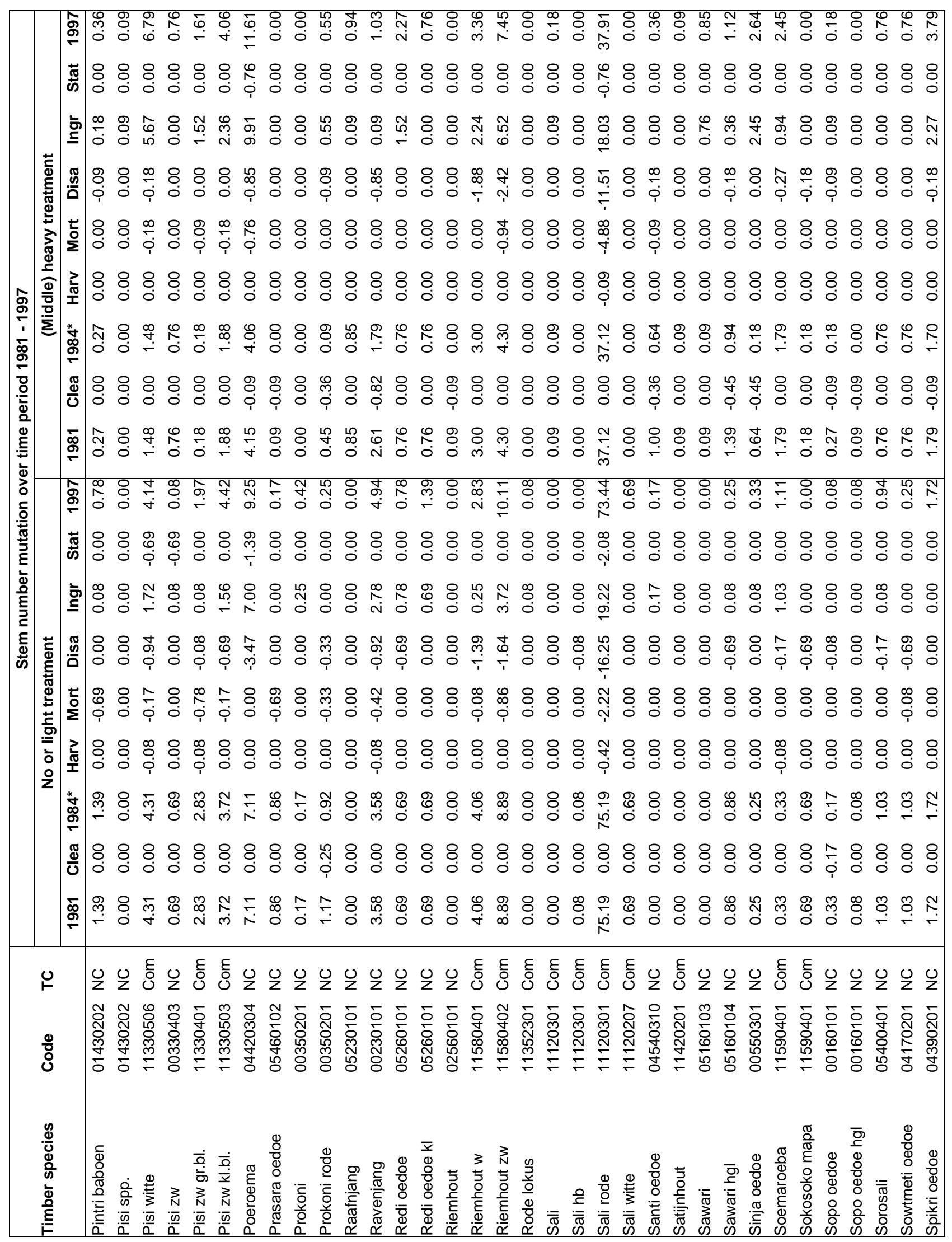




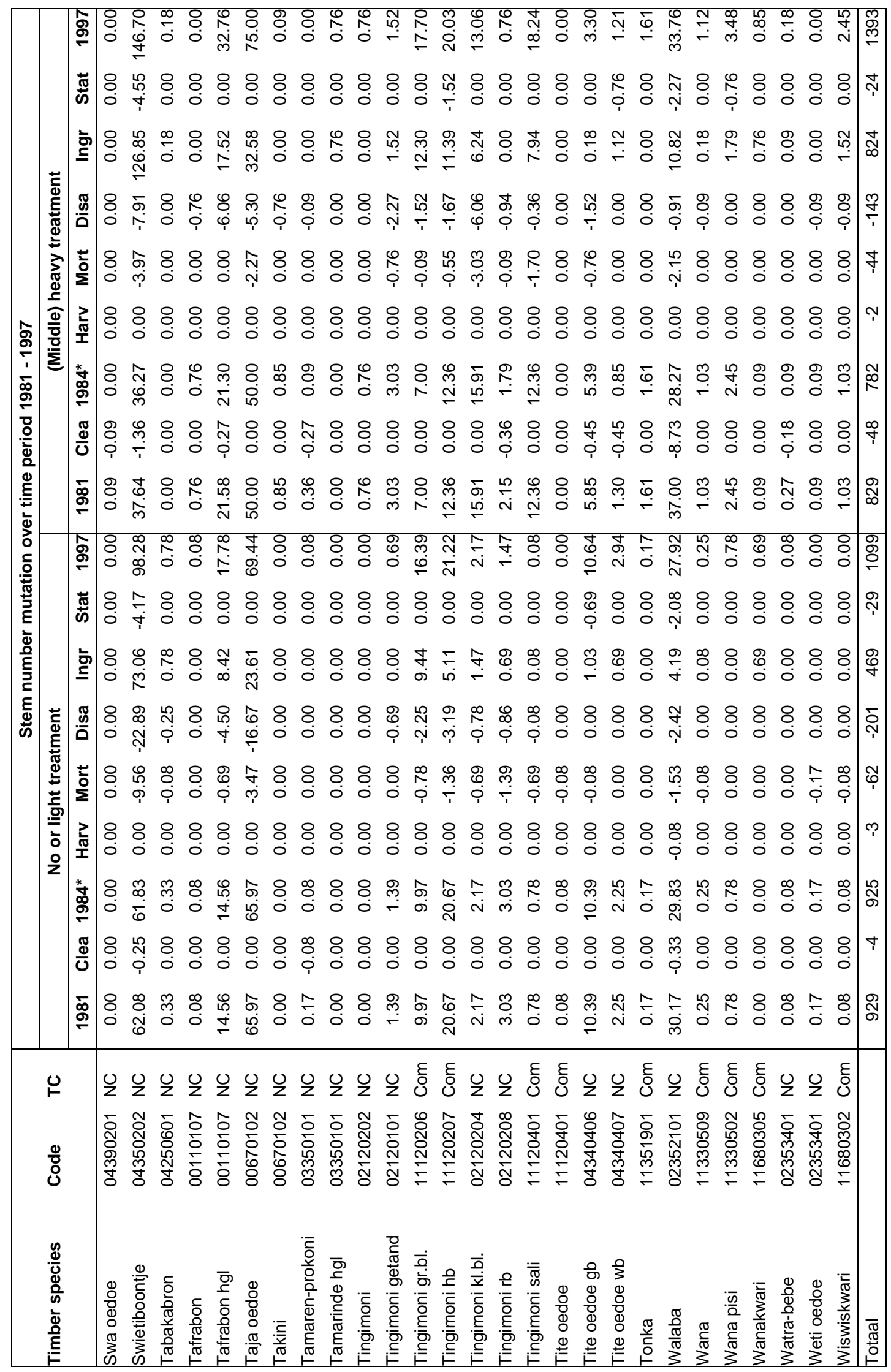

Explanation abbreviations

TC Timber class (Commercial and non-commercial)

$\begin{array}{lllll}\text { Clea Cleaning } & \text { Mort } & \text { Mortality } & \text { Ingr } & \text { Ingrowth }\end{array}$

Harv Harvest $\quad$ Disa Disappeared Stat $\quad$ Statistical mutation 


\section{Appendix III. Species list with vernacular name and scientific name}

\begin{tabular}{|c|c|c|}
\hline Vernacular name & Scientific name & Source* $^{*}$ \\
\hline Abrasa & Clusia grandiflora & Den Outer (2001) \\
\hline Agrobigi & Parkia nitida & Jonkers (2005), FAO \\
\hline Ajawa tingimoni & $\begin{array}{l}\text { Trattinickia burserifolia; T. rhoifolia; } \\
\text { Hemicrepidospermum rhoifolium }\end{array}$ & Jonkers (2005), FAO, Den Outer (2001) \\
\hline Ajo ajo & Hyeronima laxiflora; H. alchoneoides & Jonkers (2005), Den Outer (2001) \\
\hline Alanja oedoe & Swartzia arborescens & Jonkers (2005), Den Outer (2001) \\
\hline Alata oedoe & Minquartia guianensis & Jonkers (2005), Den Outer (2001) \\
\hline Anaura hgl & Licania hostmanni & FAO, Den Outer (2001) \\
\hline Anaura lgl & Licania macrophylla & Jonkers (pers. communication) \\
\hline Anaura zwamp & Licania heteromorpha & Jonkers (pers. communication) \\
\hline Apra kwari & Vochysia densiflora & FAO, Den Outer (2001) \\
\hline Apra oedoe & $\begin{array}{l}\text { Pouteria gonggrijpii; } P \text {. sagotiana; Ere- } \\
\text { moluma sagotiana }\end{array}$ & Jonkers (2005), Den Outer (2001) \\
\hline Awara oedoe & Jacaratia spinosa & Jonkers (2005), Den Outer (2001) \\
\hline Baboen hgl & Virola michelli, V. melinonii, sebifera & Jonkers (2005), FAO, Den Outer (2001) \\
\hline Baboen Igl & Virola surinamensis & Jonkers (2005), FAO \\
\hline Barklak hgl & Probably: Eschweilera odora & Jonkers (pers. communication) \\
\hline Basralokus & Dicorynia guianensis & Jonkers (2005), FAO \\
\hline Batbati & Ambelania acida; A. sagotii & Jonkers (2005), Den Outer (2001) \\
\hline Bebe & Pterocarpus officinalis & DeFilipps et al., Den Outer (2001) \\
\hline Bebe hgl & Pterocarpus rohrii & Jonkers (2005), Den Outer (2001) \\
\hline Bebe lgl & Pterocarpus sp. & \\
\hline Bergi-bebe & Swartzia benthamiana & Jonkers (2005), FAO, Den Outer (2001) \\
\hline Bergi-bita & Geissospermum sericeum & Jonkers (2005), Den Outer (2001) \\
\hline Bergi-manbarklak & Eschweilera longipes; E.pedicellata & Jonkers (2005), FAO, Den Outer (2001) \\
\hline Bitabon & unknown & \\
\hline Blaka oema & $\begin{array}{l}\text { Diospyrus guianensis; D. akaraiensis; } D \text {. } \\
\text { melinonii; Cordia macrostachya }\end{array}$ & Jonkers (2005), Den Outer (2001) \\
\hline Bofroe oedoe & Sacoglottis guianensis, S. cyonioides & Jonkers (2005), FAO, Den Outer (2001) \\
\hline Boromang & (Boroma) Cecropia peltata & Jonkers (2005) \\
\hline Bosamandel & Terminalia dichotoma; T. Iucida & Jonkers (2005), Den Outer (2001) \\
\hline Bosgujave & Calycorectes bergii & Jonkers (2005) \\
\hline Boskasjoe & $\begin{array}{l}\text { Anacardium spruceanum; A. giganteum; } \\
\text { A. occidentalis }\end{array}$ & ;Jonkers (2005), Den Outer (2001) \\
\hline Boskatoen & $\begin{array}{l}\text { Bombax crassum; B. globosum; B. ner- } \\
\text { vosum; B. surinamensis; Thespesia } \\
\text { populnea }\end{array}$ & Jonkers (2005), Den Outer (2001) \\
\hline Boskers & Eugenia coffeifolia; E. patrisii & Jonkers (2005), Den Outer (2001) \\
\hline Bosknippa & Talisia pedicullaris; T. megaphylla & Jonkers (2005); Den Outer (2001) \\
\hline Boskoeswe & Bixa orellana & Jonkers (2005) \\
\hline Boskoffie & $\begin{array}{l}\text { Coussarea paniculata; Casearia pi- } \\
\text { tumba; C. macrophylla; C. auratum }\end{array}$ & Jonkers (2005), Den Outer (2001) \\
\hline Bosmangro & $\begin{array}{l}\text { Tovomita choisyana; T. grata; } T \text {. } \\
\text { secunda; T. schomburgkii }\end{array}$ & Jonkers (2005), Den Outer (2001) \\
\hline Bospapaja & $\begin{array}{l}\text { Cecropia obtusa; C. palmata; } C . \\
\text { surinamensis }\end{array}$ & Jonkers (2005), Den Outer (2001) \\
\hline Boszuurzak & $\begin{array}{l}\text { Annona montana; } A \text {. hypoglauca; } \\
\text { Duguetia calycina; D. pycnastera }\end{array}$ & Jonkers (2005), Den Outer (2001) \\
\hline Boszuurzak zwamp & Annona glabra & Den Outer (2001) \\
\hline Botro oedoe & Gustavia hexapetala & Den Outer (2001) \\
\hline Bradilifi & Coccoloba latifolia; C. moliis & Jonkers (2005), Den Outer (2001) \\
\hline Broedoe oedoe & $\begin{array}{l}\text { Iryanthera sagotiana; I. hostmanni; } \\
\text { Couepia guianensis }\end{array}$ & Jonkers (2005), Den Outer (2001) \\
\hline Bruinhart & Vouacapoua americana & FAO, Den Outer (2001) \\
\hline Ceder & Cedrela odorata; C. guianensis & Jonkers (2005), FAO, Den Outer (2001) \\
\hline Dagoe ati & unknown & \\
\hline Dede oedoe & Capirona surinamensis & Jonkers (2005), Den Outer (2001) \\
\hline Djadidja & Sclerolobium melinonii & Jonkers (2005), FAO \\
\hline Djedoe rode & Sclerolobium albiflorum & Jonkers (2005), FAO, Den Outer (2001) \\
\hline Djedoe w & Sclerolobium paniculatom; S. guianense & Jonkers (2005), Den Outer (2001) \\
\hline Djedoe zw & Sclerolobium micropetalum & Jonkers (2005), Den Outer (2001) \\
\hline
\end{tabular}




\begin{tabular}{|c|c|c|}
\hline Vernacular name & Scientific name & Source* \\
\hline Djindja oedoe & $\begin{array}{l}\text { Buchenavia capitata; Terminalia amazo- } \\
\text { nia }\end{array}$ & FAO, Den Outer (2001) \\
\hline Djoe bolletrie & $\begin{array}{l}\text { Chrysophyllum pomiferum; C. prieuril; } \\
\text { Ecclinusa prieurii }\end{array}$ & Jonkers (2005), Den Outer (2001) \\
\hline Doifisiri & $\begin{array}{l}\text { Guarea guarea; G. guidonia; G. trichili- } \\
\text { oides }\end{array}$ & Jonkers (2005), Den Outer (2001) \\
\hline Doifisiri rode & Guarea guarea & Jonkers (pers. communication) \\
\hline Doifisiri wb & Guerea sp. & Jonkers (pers. communication) \\
\hline Doifisiri zW & Guarea kunthiana & Jonkers (2005) \\
\hline Ficus & Ficus spp. & DeFilipps et al \\
\hline Foengoe kl.bl. & Licania hupoleuca & FAO \\
\hline Foengoe rode & Parinari campestris & Jonkers (2005), FAO \\
\hline Foengoe w & Licania eliptica; Drypetes variabilis & FAO, Den Outer (2001) \\
\hline Foengoe zW & Licania micrantha & Jonkers (2005), Den Outer (2001) \\
\hline Foengoe zw kl.bl. & Licania stricta & Jonkers (2005) \\
\hline Fokofoko oedoe & Apeiba tibourbou & Jonkers (2005), Den Outer (2001) \\
\hline Foman & $\begin{array}{l}\text { (fomang) Chaetocarpus schomburgkia- } \\
\text { nus }\end{array}$ & Jonkers (2005), FAO, Den Outer (2001) \\
\hline Gandoe & Swartzia prouacensis & Den Outer (2001) \\
\hline Gandoe zW & $\begin{array}{l}\text { Schwartzia benthamiana var bentham- } \\
\text { iana }\end{array}$ & Den Outer (2001) \\
\hline Gawetri & $\begin{array}{l}\text { Cupania hirsuta; C. scrobiculata; } \\
\text { Matayba arborescens }\end{array}$ & Jonkers (2005), Den Outer (2001) \\
\hline Gawetri witte & Cupania sp. & Jonkers (pers. communication) \\
\hline Goebaja & Jacaranda copaia & Jonkers (2005), FAO, Den Outer (2001) \\
\hline Gomhout & Sapium aubletianum & Jonkers (2005) \\
\hline Granboesi-papaja & Pourouma aspera; P. laevis; P. mollis & Jonkers (2005), Den Outer (2001) \\
\hline Granboesi weti oedoe & Tapirira guianensis & Jonkers (pers. communication) \\
\hline Groenhart & Tabebuia serratifolia; T. leucoxylon & Jonkers (2005), FAO, Den Outer (2001) \\
\hline Gronfolo & Qualea coerulea & Jonkers (2005) (Laagland) \\
\hline Gronfolo bergi & Qualea rosea & Den Outer (2001) \\
\hline Gronfolo hgl & Qualea albiflora; Ruizterania albiflora & Jonkers (2005), FAO, Den Outer (2001) \\
\hline Gujavekwari & Qualea dinizii & Jonkers (2005) \\
\hline Hevea & Hevea guianensis & Jonkers (2005), Den Outer (2001) \\
\hline Hoepelhout & Copaifera guianensis & Jonkers (2005), Den Outer (2001) \\
\hline IJzerhart & $\begin{array}{l}\text { Swartzia benthamiana; S. prouacensis; } \\
\text { S. bidentata }\end{array}$ & DeFilipps et al., Den Outer (2001) \\
\hline Ingipipa & Couratari stellata & Jonkers (2005), FAO, Den Outer (2001) \\
\hline Ingipipa gr.bl. & Couratari gloriosa & Jonkers (pers. communication) \\
\hline Jakanta & $\begin{array}{l}\text { Lacistema grandifolium; Discophora gui- } \\
\text { anensis }\end{array}$ & FAO, Den Outer (2001) \\
\hline Jakanta gb & Hebepetalum humiriifolium & FAO \\
\hline Jakanta gr.bl. & Unknown & \\
\hline Jakanta hgl & Unknown & \\
\hline Jakanta rb & Dendrobangia boliviana & Jonkers (2005), FAO \\
\hline Jakanta wb & Poraqueiba guianensis & Jonkers (2005), FAO \\
\hline Jamboka & Pouteria guianensis & Jonkers (2005), FAO, Den Outer (2001) \\
\hline Jamboka rode & Pouteria guianensis & Jonkers (pers. communication) \\
\hline Jamboka zw & Pouteria cladantha & Jonkers (2005) \\
\hline Jarakopi & Siparuna guianensis; S. surinamensis & Jonkers (2005), Den Outer (2001) \\
\hline Jarijari & Anaxogorea mutica; A. dolichocarpa & Jonkers (2005), Den Outer (2001) \\
\hline Jonge kabbes & Vataireopsis speciosa & Jonkers (2005) \\
\hline Kaaiman oedoe & Laetia procera & Jonkers (pers. communication) \\
\hline Kabbes gele & $\begin{array}{l}\text { Vatairea guianensis; V. surinamensis; } \\
\text { Hymenolobium flavum }\end{array}$ & Jonkers (2005), FAO, Den Outer (2001) \\
\hline Kabbes rode & $\begin{array}{l}\text { Andira inermis; } A \text {. surinamensis; } A \text {. co- } \\
\text { riacea }\end{array}$ & Jonkers (2005), FAO \\
\hline Kabbes rode fijnbl. & Pithecellobium racemosum & Jonkers (2005) \\
\hline Kabbes rode kl.bl. & Andira spp. & FAO \\
\hline Kabbes zw & Diplotropics purpurea & Jonkers (2005), FAO \\
\hline Kabbes zw kl.bl. & Probably: Diplotropis purpurea & Jonkers (pers. communication) \\
\hline Kandra oedoe & Isertia coccinea & Jonkers (2005), Den Outer (2001) \\
\hline Kandratiki & Isertia coccinea & Jonkers (pers. communication) \\
\hline Kaneri pisi & Licaria guianensis; Mezilaurus itauba & Den Outer (2001) \\
\hline
\end{tabular}




\begin{tabular}{|c|c|c|}
\hline Vernacular name & Scientific name & Source $^{*}$ \\
\hline Kankan oedoe & Apeiba echinata; A. petouma & Jonkers (2005), Den Outer (2001) \\
\hline Kankantri & Ceiba pentandra; Bombax pentrandum & FAO, Den Outer (2001) \\
\hline Kasaba oedoe & Alchornea triplinervia & Den Outer (2001) \\
\hline Katoen oedoe & Lueheopsis flavescens; L. rugosa & Jonkers (2005), FAO, Den Outer (2001) \\
\hline Kaw-oedoe & Bagassa guianensis & Jonkers (2005), Den Outer (2001) \\
\hline Kimboto & $\begin{array}{l}\text { Pouteria ptychandra; Neopometia pty- } \\
\text { chandra }\end{array}$ & Jonkers (2005), Den Outer (2001) \\
\hline Kimboto berg & Probably: Pouteria ptychandra & Jonkers (pers. communication) \\
\hline Kimboto hgl & Probably: Pouteria ptychandra & Jonkers (pers. communication) \\
\hline Knopo-tafrabon & Cordia nodosa & \\
\hline Koenatepi & Platymiscium ulei, P. trinitatis & Jonkers (2005), FAO, Den Outer (2001) \\
\hline Kokriki & $\begin{array}{l}\text { Ormosia paraensis; O. fastigiata; } O . \\
\text { melanocarpa }\end{array}$ & Jonkers (2005), Den Outer (2001) \\
\hline Kokriki hgl & Ormosia coccinea & Jonkers (2005), Den Outer (2001) \\
\hline Konkoni oedoe & Gustavia augusta & Jonkers (pers. communication) \\
\hline Konkoni oedoe hgl & Gustavia hexapetala & Jonkers (2005) \\
\hline Kopi & Goupia glabra; G. tomentosa & Jonkers (2005), FAO, Den Outer (2001) \\
\hline kototiki & Mabea piriri & Jonkers (2005) \\
\hline Kototiki & Mabea piriri & Jonkers (2005) \\
\hline Krabasi oedoe & Terminalia amazonia; T. obovata & Den Outer (2001) \\
\hline Krapa & Carapa guianensis; C. procera & FAO \\
\hline Kraspisi & Ocotea glomerata; O. caudata & FAO, Den Outer (2001) \\
\hline Kromanti kopi & $\begin{array}{l}\text { Aspidosperma cruentum, A. sandwichia- } \\
\text { num }\end{array}$ & Jonkers (2005), FAO, Den Outer (2001) \\
\hline Kwari rode & $\begin{array}{l}\text { Vochysia guianensis; V. melinnonii; V. } \\
\text { neglectum }\end{array}$ & $\begin{array}{l}\text { Den Outer (2001), Jonkers (pers. com- } \\
\text { munication) }\end{array}$ \\
\hline Kwasiba & (Akwasiba) Pouteria cuspidata & Den Outer (2001) \\
\hline Kwaskwasi oedoe & Ampelocera edentula & Jonkers (2005) (without oedoe) \\
\hline Kwatabobi & Ecclinusa cuneifolium & Jonkers (2005) \\
\hline Kwatakama & Parkia pendula; Inga pendula & Jonkers (2005), Den Outer (2001) \\
\hline Kwatapatoe & Lecythis davisii & FAO \\
\hline Kwepi & Licania apetala & Jonkers (2005), Den Outer (2001) \\
\hline Kwepi hb & Probably: Licania apetala & Jonkers (pers. communication) \\
\hline Kwepi rode & Excellodendron barbatum & Jonkers (2005) \\
\hline Laksiri hgl & Caraipa sp. & Jonkers (pers. communication) \\
\hline Laurierkers & $\begin{array}{l}\text { Ecclinusa cuneifolia; Chrysophyllum cu- } \\
\text { neifolium }\end{array}$ & Den Outer (2001) \\
\hline Leletiki & Rinorea spp. & Jonkers (2005) \\
\hline Letterhout & $\begin{array}{l}\text { Brosimum guianense; B. rotundatum; } P \text { i- } \\
\text { ratinera scabridula; } P \text {. guianensis }\end{array}$ & i-Jonkers (2005), FAO, Den Outer (2001) \\
\hline Lika oedoe & Antonia ovata & Jonkers (2005), Den Outer (2001) \\
\hline Makakabbes & $\begin{array}{l}\text { Hymenolobium flavum; Enterolobium } \\
\text { schomburgkii }\end{array}$ & Jonkers (2005), Den Outer (2001) \\
\hline Man-bebe berg & Alchorneopsis trimera & $\begin{array}{l}\text { Jonkers (2005), Den Outer (2001), } \\
\text { Jonkers (pers. communication) }\end{array}$ \\
\hline Man-sali & Conceveiba guianensis & Den Outer (2001) \\
\hline Manaritiki & Rinorea passoura & Jonkers (2005) \\
\hline Manbarklak & $\begin{array}{l}\text { Eschweilera subglandulosa; E. orrugata; } \\
\text { Lecythis idatimon; L. corrugata }\end{array}$ & ; Jonkers (2005), FAO \\
\hline Manbarklak hgl & Eschweilera odora; E. coriacea & Jonkers (2005), FAO, Den Outer (2001) \\
\hline Manbebe & Alchorneopsis trimera & Den Outer (2001) \\
\hline Manbospapaja & Cecropia sciadophylla; C. sciadophylla & Jonkers (2005), Den Outer (2001) \\
\hline Manletterhout & Perebea laurifolia; Brosimum guianense & Jonkers (2005), Den Outer (2001) \\
\hline Manpikapika & Unknown & \\
\hline Manpinja & Vismia angusta & Jonkers (2005) \\
\hline Mantakina & Unknown & \\
\hline Mapa & $\begin{array}{l}\text { Ambelania acida; A. sagotii; Couma } \\
\text { guianensis; Macoubea guianensis }\end{array}$ & Den Outer (2001), FAO \\
\hline Marmadosoe & $\begin{array}{l}\text { Amaioua guianensis; Amajoua guianen- } \\
\text { sis }\end{array}$ & Den Outer (2001) \\
\hline Marmadosoe gr.bl. & Duroia sp. & Jonkers (pers. communication) \\
\hline Marmadosoe kl. & Duroia sp. & Jonkers (pers. communication) \\
\hline Mataki & $\begin{array}{l}\text { Symphonia globulifera; Caraipa densi- } \\
\text { flora }\end{array}$ & Jonkers (2005), FAO \\
\hline Mataki hgl & Symphonia gabonensis & FAO \\
\hline
\end{tabular}




\begin{tabular}{|c|c|c|}
\hline Vernacular name & Scientific name & Source* \\
\hline Mataki lgl & Unknown & \\
\hline Mawsikwari & Vochysia guianensis & FAO \\
\hline Melisali & Trichilia propingue & Jonkers (2005), FAO \\
\hline Merkitiki & Bonafousia undulata & Jonkers (2005) \\
\hline Miera oedoe & Symmeria paniculata & Den Outer (2001) \\
\hline Mispel & $\begin{array}{l}\text { Miconia longifolia; M. mucranata, a.o. } \\
\text { (Bosmispel)Bellucia grossularioides }\end{array}$ & Jonkers (2005), Den Outer (2001) \\
\hline Mispel gr.bl. & Miconia sp. & Jonkers (pers. communication) \\
\hline Moetene & Capirona decorticans & \\
\hline Nekoe oedoe & $\begin{array}{l}\text { Alexa wachenheimii; Lonchocarpus lati- } \\
\text { folius }\end{array}$ & Jonkers (2005), FAO, Den Outer (2001) \\
\hline Njamsi oedoe & Guapiri olfersiana; Torrubia olfersiana & Jonkers (2005), Den Outer (2001) \\
\hline Njamsi oedoe kl & Torrubia olfersiana & Den Outer (2001) \\
\hline Oema oedoe & Casearea javitensis & Jonkers (2005), Den Outer (2001) \\
\hline Oemanbarklak & $\begin{array}{l}\text { Eschweilera amara; Arrabidaea } \\
\text { inaequalis }\end{array}$ & FAO, Den Outer (2001) \\
\hline Oemanbarklak hgl & $\begin{array}{l}\text { Lecythis corrugata; Eschweilera corru- } \\
\text { gata }\end{array}$ & Jonkers (2005), FAO, Den Outer (2001) \\
\hline Oeproe olie & Copaifera guianensis & Den Outer (2001) \\
\hline Okro oedoe & Sterculia pruriens; S. excelsa & Jonkers (2005), Den Outer (2001) \\
\hline Olie oedoe & Trynatococcus amazonicus & Jonkers (2005) \\
\hline Onbekend & Unknown & \\
\hline Pakira tiki & Tapura guianensis & Jonkers (2005) \\
\hline Pakoeli hgl & Rheedia macrophylla & Jonkers (2005), FAO \\
\hline Pakoeli lgl & Unknown & \\
\hline Panga panga & $\begin{array}{l}\text { Palicourea guianensis, Milettia } \\
\text { stuhlmannii (from east africa) }\end{array}$ & Jonkers (2005), Den Outer (2001) \\
\hline Panga panga gr.bl. & Palicourea guianensis & Jonkers (pers. communication) \\
\hline Panga panga hgl & Palicourea guianensis & Jonkers (pers. communication) \\
\hline Panga panga kl.bl. & unknown & \\
\hline Panta hgl & Conceveiba guianensis & Jonkers (2005) \\
\hline Panta Igl & Unknown & \\
\hline Panta wb & Unknown & \\
\hline Parelhout & Aspidosperma sp. & Jonkers (pers. communication) \\
\hline Parelhout wit & Aspidosperma marcgravianum & Jonkers (2005), Den Outer (2001) \\
\hline Parelhout zw & Aspidosperma exelsum & Jonkers (2005), Den Outer (2001) \\
\hline Pegrekoe-pisi & Xylopia aromatica, $X$. nitida & Jonkers (2005), FAO, Den Outer (2001) \\
\hline Pegrekoe-pisi rood & Xylopia spec. & Jonkers (pers. communication) \\
\hline Pegrekoe-pisi w & Probably: Xylopia aromatica & Jonkers (pers. communication) \\
\hline Pepre oedoe & Pera bicolor & Jonkers (2005), Den Outer (2001) \\
\hline Pera & Couma guianensis & Jonkers (2005), Den Outer (2001) \\
\hline Pikin-misiki & $\begin{array}{l}\text { Piptadenia suaveolens; Newtonia } \\
\text { suaveolens }\end{array}$ & FAO \\
\hline Pikin kwepi & Probably: Licania obidensis & Jonkers (pers. communication) \\
\hline Pikinmisiki & Piptadenia suaveolens & Jonkers (2005) \\
\hline Pikintiki & Maprounea guianensis & Jonkers (2005) \\
\hline Pinja oedoe & Vismia sp. & Jonkers (2005), Den Outer (2001) \\
\hline Pinto-kopi & Laetia procera & Jonkers (2005), Den Outer (2001) \\
\hline Pinto-kopi hg & Laetia spec. & Jonkers (2005) \\
\hline Pintobolletri & Pouteria cuspidate; P. robusta & Jonkers (2005), Den Outer (2001) \\
\hline Pintolocus zwarte & Unknown & \\
\hline Pintolokus witte & $\begin{array}{l}\text { Martiodendron parviflorum, Martiusisa } \\
\text { parviflora }\end{array}$ & Jonkers (2005), FAO \\
\hline Pintolokus zwarte & Unknown & \\
\hline Pintri baboen & Virola sebifera & Jonkers (2005), FAO \\
\hline Pisi spp. & $\begin{array}{l}\text { Aniba taubertiana (pisi), Nectandra am- } \\
\text { bigua; a.o. }\end{array}$ & Den Outer (2001) \\
\hline Pisi witte & Ocotea canaliculata; O. petalanthera & Jonkers (2005), FAO, Den Outer (2001) \\
\hline Pisi zw & $\begin{array}{l}\text { Nectandra pisi; N. grandis, Ocotea glo- } \\
\text { merata }\end{array}$ & Jonkers (2005), FAO, Den Outer (2001) \\
\hline Pisi zw gr.bl. & Nectandra grandis & FAO, Den Outer (2001) \\
\hline Pisi zw kl.bl. & Nectandra cf Ocotea wachenheimii & FAO \\
\hline Poeroema & Pourouma digitata & Den Outer (2001), Den Outer (2001) \\
\hline Prasara oedoe & Guapira spp. & Jonkers (2005) \\
\hline
\end{tabular}




\begin{tabular}{|c|c|c|}
\hline Vernacular name & Scientific name & Source* \\
\hline Prokoni & Inga alba & Jonkers (2005) \\
\hline Prokoni rode & Inga aff. Alba & FAO \\
\hline Raafnjang & Sloanea trichosticha & Jonkers (2005) \\
\hline Ravenjang & Sloanea trichosticha & Jonkers (2005) \\
\hline Redi oedoe & Casearea arborea & Jonkers (2005), Den Outer (2001) \\
\hline Redi oedoe kl & Unknown & \\
\hline Riemhout & $\begin{array}{l}\text { Chrysophyllum argenteum; Microphyllus } \\
\text { venulosa }\end{array}$ & Den Outer (2001) \\
\hline Riemhout w & $\begin{array}{l}\text { Micropholis guyanensis var. guyanensis; } \\
\text { Sideroxylon guianensis }\end{array}$ & Jonkers (2005), FAO, Den Outer (2001) \\
\hline Riemhout zw & Micropholis guyanensis var commixta & Jonkers (2005), FAO, Den Outer (2001) \\
\hline Rode lokus & Hymenaea courbaril & DeFilipps et al., Den Outer (2001) \\
\hline Sali & $\begin{array}{l}\text { Tetragastris spp.; Guerea kunthiana; } \\
\text { Hemicrepidospermum rhoifolium; Pro- } \\
\text { tium alstonii }\end{array}$ & FAO, DeFilipps et al., Den Outer (2001) \\
\hline Sali hb & Unknown & \\
\hline Sali rode & Tetragastris altissima & Jonkers (2005), FAO, Den Outer (2001) \\
\hline Sali witte & Protium polybotryum; P. glabrescens & Den Outer (2001) \\
\hline Santi oedoe & Licania ovalifolia & Jonkers (2005), FAO, Den Outer (2001) \\
\hline Satijnhout & Brosimum paraënse & Jonkers (2005), FAO \\
\hline Sawari & Caryocar nuciferum & FAO, Den Outer (2001) \\
\hline Sawari hgl & Caryocar glabrum & Jonkers (pers. communication) \\
\hline Sinja oedoe & Chimarrhis turbinata & Jonkers (2005), Den Outer (2001) \\
\hline Soemaroeba & Simarouba amara; Quassia amara & Jonkers (2005), FAO, Den Outer (2001) \\
\hline Sokosoko mapa & Macoubea guianensis & Jonkers (2005) \\
\hline Sopo oedoe & Endlicheria multiflora & FAO, Den Outer (2001) \\
\hline Sopo oedoe hgl & Carycar spec. & Jonkers (pers. communication) \\
\hline Sorosali & Trichilia roraimana; $T$. surinamensis & Jonkers (2005), Den Outer (2001) \\
\hline Sowtmeti oedoe & Maytenus myrsinoides & Den Outer (2001) \\
\hline Spikri oedoe & Mouriri acutiflora & Jonkers (2005), Den Outer (2001) \\
\hline Swa oedoe & Laplacea fructicosa & Jonkers (2005) \\
\hline Swietiboontje & Inga spp. & Jonkers (2005) \\
\hline Tabakabron & Croton matourensis & Jonkers (2005), Den Outer (2001) \\
\hline Tafrabon & Cordia tetrandra & Den Outer (2001) \\
\hline Tafrabon hgl & Cordia laevifrons & Jonkers (pers. communication) \\
\hline Taja oedoe & Paypayrola guianensis & Jonkers (2005), Den Outer (2001) \\
\hline Takini & $\begin{array}{l}\text { Brosimum acutifolium; Helicostylis to- } \\
\text { mentosa }\end{array}$ & DeFilipps et al. \\
\hline Tamaren-prokoni & $\begin{array}{l}\text { Macrosamanea pedicellaris; Balizia ped- } \\
\text { icellaris; Enterolobium schomburgkii }\end{array}$ & FAO, Den Outer (2001) \\
\hline Tamarinde hgl & Probably: Pithecellobium corymbosum & Jonkers (pers. communication) \\
\hline Tingimoni & Protium arachouchini a.o. & Jonkers (2005) \\
\hline Tingimoni getand & Hemicrepidospermum rhoifolium & Jonkers (2005), FAO, Den Outer (2001) \\
\hline Tingimoni gr.bl. & Protium spp. & FAO \\
\hline Tingimoni hb & Protium sagotianum & FAO \\
\hline Tingimoni kl.bl. & Protium heptaphyllum & Jonkers (2005) \\
\hline Tingimoni rb & Protium polybotryum & Jonkers (2005), FAO \\
\hline Tingimoni sali & Tetragastris hostmannii, T. panamensis & Jonkers (2005), FAO \\
\hline Tite oedoe & Lecythis sp. & Jonkers (pers. communication) \\
\hline Tite oedoe gb & Eschweilera chartacea; E. poiteaui & Jonkers (2005), Den Outer (2001) \\
\hline Tite oedoe wb & Lecythis simiorum; L. chartacea & Jonkers (2005), Den Outer (2001) \\
\hline Tonka & $\begin{array}{l}\text { Dipterix odorata; } T \text {. cayennensis; } \\
\text { Dipteryse oderata; D. puntata }\end{array}$ & Jonkers (2005), FAO \\
\hline Walaba & Eperua falcata & Jonkers (2005), FAO \\
\hline Wana & Ocotea rubra; Nectandra rubra & Jonkers (2005), FAO, Den Outer (2001) \\
\hline Wana pisi & $\begin{array}{l}\text { Ocotea globifera; O. puberula; O. } \\
\text { schomburgkiana }\end{array}$ & Jonkers (2005), FAO, Den Outer (2001) \\
\hline Wanakwari & Vochysia tomentosa & Jonkers (2005), FAO \\
\hline Watra-bebe & Pterocarpus officinalis & FAO, Den Outer (2001) \\
\hline Weti oedoe & Tapirira guianensis & Jonkers (2005), Den Outer (2001) \\
\hline Wiswiskwari & Vochysia guianensis; $V$, surinamensis & Jonkers (2005), FAO, Den Outer (2001) \\
\hline
\end{tabular}

Notice: it was not clear for all species, which one was actually meant. Many different specifiers are used and thus for some no scientific name could be given. 


\section{* References}

- Den Outer, R.W. (2001) Vernacular names of Surinam woody plants, Department of Plant Cytology and Morphology, Wageningen University, Netherlands.

- Jonkers, W.B.J., Tjon, K. and Wirjosentono, J. (2005, in prep.). Long-term changes in selectively logged and silviculturally treated tropical rain forest in Suriname: Analysis of the 1978-2000 data of Experiment 78/5. Department of Environmental Sciences, Wageningen University, Netherlands

- $\quad$ FAO, Appendix 1. List of tree species, http://www.fao.org/docrep/003/y2698e/y2698e12.htm last visited at 7-12-2004

- $\quad$ DeFilipps, Robert A., Maina, Shirley L., Crepin, Juliette, Medicinal Plants of the Guianas (Guyana, Surinam, French Guiana), http://www.mnh.si.edu/biodiversity/bdg/medicinal/ last visited at 30-12-2004 


\section{Appendix IV. Terms of Reference: Statistical Analysis of Forest Research Data (Mapane-Experiment)}

\section{Background}

In 1980 a semi-practical scale experiment (640 ha) on natural forest regeneration was started by the Suriname Forest Service (LBB) in the Mapane Area. The by then most promising CMS variant (gecontroleerde oogst followed by elimination of non-commercial tree species retaining a total basal area of $15 \mathrm{~m} 2$ per ha) would be carried out in a 640 ha forest area at Akintosoela. Due to financial constraints however, the planned silvicultural treatment could only be applied to 23 Permanent Sample Plots (PSP's) of 1 ha, randomly distributed over the selectively logged experimental area.

In 1981 these PSP's were assessed for the first time. AII trees within these PSP's with dbh > $15 \mathrm{~cm}$ were identified up to the local name level, their diameter and height were measured and the stem- and crown form were assessed. Regeneration (saplings and young trees) of commercial species between 2 and $15 \mathrm{~cm}$ dbh were recorded in 3 randomly selected central quadrants of 20 x $20 \mathrm{~m} 2$ within these PSP's. The local species name and the diameter and height were recorded.

In 1983/1984 non-commercial tree species were eliminated in these PSP's, leaving a total basal area of 12.5 to $15 \mathrm{~m} 2$ per ha.

In 1995 CELOS restarted its Forestry Research Programme and adopted this experiment. In 1997/1998 a re-assessment of these PSP's was carried out by CELOS. The same parameters were assessed as in 1981.

There are now two complete data sets filed at CELOS, which need to be analyzed to determine the effects of the applied CMS treatment (gecontroleerde oogst followed by one refinement only) after 20 years.

\section{Objectives.}

- Statistical analysis of the data sets (1981-1998) provided by the CMS treatment of the plots in the Mapane-region.

- Production of a procedure (manual) for computer analysis of forest tree data.

\section{Terms of Reference.}

Following is a TOR for a forest statistician / biometrist for the analysis of these two datasets.

A. Under the supervision of CELOS' Forestry Department and based on these two data sets (assessments of 1981 and 1997/1998) the statistician will undertake the following activities:

> Determine the increment in terms of number of trees per ha, basal area per ha and volume per ha of commercial and non-commercial species, taking into account the expansion of the list of commercial species since 1980.

$>$ Determine the annual diameter/girth increment of commercial, non-commercial and 10 to 15 most common species as a group and individually, within the PSP's.

> Determine the total and annual mortality in terms of number of trees per ha, basal area per ha and volume per ha of commercial and non-commercial species within the PSP's. 
> Determine the total and annual ingrowth/recruitment in terms of number of trees per ha, basal area per ha and volume per ha of commercial and non-commercial species, within the PSP's.

$>$ Determine changes in species composition of the PSP's, if any.

> Determine changes in frequency per diameter-class (diameter-class frequency) for commercial and non-commercial species within the PSP's, if any.

B. Procedure of analysis

$>$ The statistician will prepare a "Procedure" for the computer analysis of the data sets, listing the most appropriate/used software programs and the step-by-step procedures for the above listed determinations. This "Procedure" will have such a format that it can be used independently by CELOS technicians as a manual for forest/tree data analysis.

C. Qualifications

D The statistician should be a professional forest statistician or biometrist with experience in Tropical Silviculture or Tropical Forest Research Programs.

D. Reporting

$>$ The statistician will prepare a technical report of the results of the statistical analysis of the two data sets with recommendations for possible follow-up research. 